\title{
IETS OVER DE PANTONS OF MINNEZANGEN DER MALEIJERS.
}

De bij den Maleijer zoo zeer geliefde panton's, die voor hem al de aantrekkelijkheid eener verbodene vrucht hebben, zijn voor de kennis van taal en volk als zeer belangrijke voortbrengselen op het gebied der Maleische litteratuur, waartoe ze voorzeker behooren, te beschouwen.

Bij deze soort van gedichten is de opsteller aan geen ander onderwerp gebouden dan aan dat, wat hem het liefste is de $\min$. Hij spreekt zich daarin vrij en ongedwongen uit; haalt alles, wat in de lucht, op de aarde en in het water is, overhoop, 't zij om het rijmwoord te krijgen of om maar wat te kunnen zeggen, en vlecht er bij voorkeur zijne spreekwoorden en puntige gezegden in.

Opuerkelijk ziju vooral de vele stellingen uit het ongerijmde, die er in voorkomen en die ons kumen doen zien, dat den Malijers geen Witz ontbreekt. Juist die geven ous dikwerf zijne spreekwoordeu aan de hand. Voorbeelden daarvan zijn: Poetik soedah mëndjadi boenga, Djaroem disimpan mëndjadi pakoe. Apakan goena pasang pèlita, Djikalan tidak dèngan soemboenja. Djika sa'riboe zanggi měnglhedan, Dewa nen tidak gěntar dan ngëri. Sa'eikoer koeman kěna pělëntik, Sa'kalian alam limpah darahnja en vele andéren.

Dat de Europeanen, die het Maleisch hebben beoefend, tot heden nog niets 1 van die panton's hebben in 't licht gegeven, is, meen ik, daaraan toe te schrijven, dat ze zelden in handen van een Europeaau komen. De Maleijers houden ze verborgen, dikwerf zelfs voor hunne eigene volksgenooten, daar humne

1 Ik zeg niets; want de verminkte stukjes door Marsden op- eu door Dr. de Hollander, bij gebrek aan beter, overgenomen, zijn inderdaad als niets te beschouwen, 
priesters ze, figuurlijk gesproken op de lijst der verbodene boeken hebben geschreven en dat wel bovenaan, omdat de inhoud dier minnedichten hun nog meer ergert dan die der Hikajat's en Sjair's.

De pantons toch bevatten soms zeer onkiessche uitdrukkingen en zinspelingen, waaruit men de verregaande rinnelijkheid van het volk kan leeren kennen. 't Is echter niet zoozeer daarom dat de priesters er tegen zijn, als wel omdat ze niet over de godsdienst handelen en er dikwerf voor hen zeer gevoelige Seitenhiebe in voorkomen.

Daar dus de inhoud dier pantons ze weinig geschikt maakt om ze in leesboeken of bloemlezingen op te nemen en ze toch in het belang der taalstudie wel meer gekend dienen te worden, heb ik besloten deze verzameling afzonderlijk uit te geven.

Het hier geleverde is op slechts vier coupletten na in zijn geheel, zooals ik het van de Maleijers op Riouw heb ontvangen. Eerst had ik er nog eene verbeterde bloemlezing van Bataviasche pantons aan toegevoegd, doch daar die in den handel verkrijgbaar zijn, ben ik daarvan teruggekomen. Buiten het hier geleverde zijn nog twee bundels van Riouw in mijn bezit, die $\mathrm{ik}$, om niet te uitvoerig te worden, maar achterwege laat.

De oplettende lezer zal aan dit weinige kunnen zien, dat de constructie der pantons geheel anders is dan men tot nog toe heeft beweerd en verondersteld. Volgens de opgave der Maleijers wordt voor elken regel, zoowel van de panton als van desjair, niet een zeker aantal lettergrepen, maar bepaald vier woorden geeischt, onverschillig of die woorden twee- dan wel meer lettergrepig zijn. Wanneer ze echter te veel lettergrepen hebben om gevoegelijk vier te kunnen gebruiken dan bepaalt de dichter zich slechts tot drie. Ook worden sommige zamengestelde woorden wel eens als twee afzonderlijke beschouwd, b. v. بارغٔالي

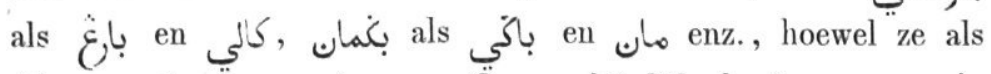
één woord zij̄n geschreven. Ö̈ogenschijnlijk heeft een regel, waarin zulke woorden voorkomen, dan slechts drie, doch inderdaad vier woorden.

Het onderscheid tusschen panton en sjair, daargelaten dat de eerste minne-, de laatste heldendicht is, bestaat daarin, dat bij de sjair elke regel rijmt op den oumiddellijk voorgaanden, terwijl bij de panton de derde op den eersten en de vierde op den tweeden regel moet rijmen. Verder moet ik doen opmerken, dat het niet alleen de slotwoorden van elken regel zijn, die men op elkander rijmen laat, maar dat er veel geneigdheid bij 
de dichters bestaat, om ook de overige woorden van den eenen regel zooveel mogelijk gelijkluidend met die van den anderen te maken. Eene oppervlakkige beschouwing van sommige coupletten kan dit reeds doen zien.

Ook is het bij de panton een vereischte, dat de coupletten aan elkander geketend zijn, zooals de Maleijers zeggen: bërkajit-kajit, door den tweeden regel van een voorgaand couplet tot den eersten van een volgend te maken; b. v.

Koepoe-koepoetĕrbang mĕlintang, Tĕrbang dilaoet dihoedjoeng karang;

Hati didalam mĕnaroeh bimbang

Dari dahoeloe sampei sakarang.

Tĕrbang dilaoet dihoedjoeng karang Boeroeng nasar tĕrbang ka Bandan;

Dari dahoeloe sampei sa'karang

Banjak moeda soedah koe-pandang.

Soms wordt ook, zooals hier, de vierde regel van een voorgaand tot den derde van een volgend couplet gemaakt, doch dit is geen volstrekt vereischte.

Dat deze aaneenschakeling niet altijd in de hier geleverde pantons voorkomt is daaraan toe te schrijven, dat het verschillende, door de Maleijers bijeenverzamelde brokstukken zijn.

Eene zekere mat of cadence bestaat voorzeker in de Maleische gedichten, vooral in de panton's; hoe zouden deze laatsten anders ook kunnen gezongen worden met begeleiding der viool, gelijk veelal plaats heeft? De dichters en afschrijvers zondigen echter zóó dikwerf tegen die maat, dat wij in een ongecorrigeerd gedicht haar moeijelijk kumnen ontdekken. Of onze middeneeuwsche zangers het daarin echter van de Maleische winnen, durf ik niet beslissen, en onderwerp mij an het oordeel van Werndly, als hij, na de aanhaling van een Maleisch vers, zegt: "Wanneer ik dit gedicht met de Nederduitsche gedichten van " voorgaande eeuwen wilde vergelijken, zou 't zelve nog al boven "die uitmunten, en daarom zijn de Maleische gedichten niet "te verachten, al zijn ze zoo naauwkeurig als onze hedendaag"sche niet opgesteld, en zullen dezelve mogelijk met den tijdt, " wanneer de geleerdheit wat meer onder hen zal bloeien, ook " veel beter en beschaafder worden." 
Het zondigen tegen de prosodie baart evenwel den Maleischen troubadour niet veel bezwaar, daar hij zoowel eenige lettergrepen op één maatslag kan zingen als één lettergreep rekken om de maat vol te maken.

Het is waar, dat de panton's vroeger bij huwelijks- en andere feesten, bij wijze van wedstrijd werden gezongen. 1 Dit blijkt overvloedig uit de Hikajat's, zelfs de oudste, waarin nog van geen sjair sprake is. Tegenwoordig heeft dit echter zelden plaats. Alleen hoort men dikwerf nog eenige Maleijers des avonds bij maneschijn in een sampan (bootje) op zee dobberende of op de leuning van een brug gezeten, met de viool in de hand hunne panton's opdreunen, wat niet onaardig klinkt.

Over het algemeen hebben de Maleijers meer gevoel en aanleg voor muziek dan de Javanen, hoewel hunne eigene instrumenten (en dit is, dunkt me, wel een bewijs voor mijn beweren) meer en meer in onbruik raken. Vele instrumenten, waarvan de namen in de Hikajat's voorkomen, zijn tegenwoordig voor den gewonen Maleijer hier even onbekende zaken als voor ons. Daarentegen treft men te Batavia, Samarang, Soerabaja en Singapoera troepen van Maleische strassen-virtuosen aan, die voor hun doen wel aardig Europesche muziek op Europesche instrumenten spelen. De viool, schuiftrompet, clarinet, turksche trom, triangel en bekkens spelen daarbij natuurlijk de hoofdrol, geheel overeenkomstig , het volkskarakter.

Met een enkel woord moet ik hier nog gewag maken van den rijkdom der Maleische litteratuur aan dichtwerken. De gissing van Dr. de Hollander op pag. 295 van zijne Handleiding bij de beoefening der Maleische taal en letlerkunde 3e druk " dat zij slechts een betrekkelijk gering aantal dichterlijke voortbrengselen zou tellen" bevestigt zich niet. Hier te Riouw zijn meer dicht- dan prozawerken te verkrijgen. Ten bewijze daarvan verwijs ik nąar eene opgave der onder mij berustende dichtwerken door mij geplaatst in de notulen van het Batav. Gen. van K. en W. Dl. IV afl. 2 pag. 192-197, 1867. Deze lijst bevat. bij lange na niet alles wat hier te verkrijgen is. ${ }^{2}$

1 Dat de langere gedichten van dien aard dendang zouden heeten is onjuist, daar dit woord zingen beteekent.

2 Van eene geachte zijde daartoe verzocht zal ik die lijst ook hier aan toevoegen en op de aanteekeningen laten volgen, daar slechts zeer weinigen, en wel cerst een paar jaren na de uitgave, in de gelegenheid komen dat Tijdschrift te raadplegen. 
Het is- mij duidelijk gebleken, dat men verkeerd doet der Maleische letterkunde meer dan twee dichtsoorten, de panton en de sjair, toe te kennen en dat nog wel op grond van de kroon aller koningen, die zoovele kenteekenen draagt van door een perranakan arab te zijn geschreven. Zelfs de goerindam's zijn den Maleijer onbekend, al heeft ook Radja Ali Hadji door het opstellen van een paar hun aanwezen willen bewijzen. In de oudste HS. vindt men alleen gewag gemaakt van panton en saloka, in die van lateren tijd leest men slechts van sjair en panton. Te betreuren is het, dat de goede HSS. onder de Maleijers meer en meer verloren gaan.

Van het bundeltje, dat ik hier de beoefenaren van het Maleisch aanbied, kan ik geen vertaling leveren, omdat deze soort van gedichten ten eenenmale ongeschikt is om in onze taal te worden overgegoten. Men overtuige zich daarvan met deze eenigzins vrije overzetting der eerste regels en men zal mij gaarne vergeven, dat ik de rest overtaald heb gelaten.

Dit is een pas opgesteld werk, De schrijver er van verstaat niet veel. Er was eene enkele bloem bloeijende, Groeijende op den top eens hoogen bergs. De schrijver er van verstaat niet veel. De taal van dien mensch is de Maleische. Groeijende op den top eens hoogen bergs. Die bloem bloeide met een purperen glans. De taal van dien mensch is de Maleische. De schrijver begrijpt de beteekenis niet. Die bloem bloeide met een purperen glans. De koembang ging onophoudelijk daarheen. Bloemen gevlochten in den tuin, In den lusttuin van Djoedah's koning. Ik ben niet gewoon panton's te dichten; Voor de fouten vraag ik verschooning; Vraag vergeving voor de redenen, die te vergaan. De angsana-boom spruit op de steenen uit; De uitspruitsels worden bij duizenden overgeplant. Er zijn bloemen, die door steenen worden beschaduwd;

Wier gesloten knop van glas en wier steel van dauw is, 
De uitspruitsels worden bij duizenden overgeplant.

Wordt de koembang tot vechten aangehitst dan keert en weidthij zich.

De geslotene knop er van is vanglas en de steel is van dauw;

Mag slechts bekeken maar niet genomen worden. enz.

Van de aanteekeningen heb ik echter des te meer werk gemaakt en daarbij de gelegenheid waargenomen om eenige onjuistheden van het Maleische woordenboek aan te toonen.

Ter voorkoming van vergissing moet ik opmerkzaam maken op de verbinding van akan met het onmiddellijk voorgaande woord, zooals b. v. in manakan, inikan, siapakan, hampirkan enz. voor mana akan, ini akan, siapa akan en hampir akan. Dit geschiedt in gedichten dikwerf om een woord uit te winnen. Ook wordt hier de angka doewa niet gebruikt en de reduplicatie van een woord voluit geschreven, daar anders in een regel voor het gezigt een woord zou ontbreken. Ook moet men bij de lezing onthouden, dat door toewan meestal en door adinda en adik altijd het angebeden meisje, door abang, $k a-$ kanda en koembang de minnaar wordt angeduid.

Opmerkelijk is het gebruik van moe in plaats van dikau achter déngan en akan in déngan moe toewan, akan moe toewan.

Bij mijne aanteekeningen is de heer von Dewall mij met zijne jaren lange ondervinding te hulp gekomen, waarvoor ik hier zijn Ed. Gestr. openlijk mijn dank betuig.

Hopende met dit weinige weder iets te hebben bijgedragen tot de nadere kennis van het Maleisch en den Maleijer beveel ik het in de verschoonende belangstelling der liefhebbers aan.

Riouw, 25 April 1866.

H. C. Kinnkert. 
IETS OVER DE PANTONS DER MALEIJERS.

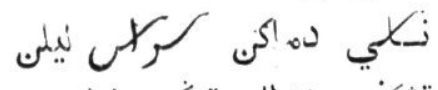
تقكف ددالم تيكس فول

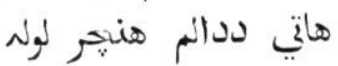
هنيبر جال هفنجة فنتي

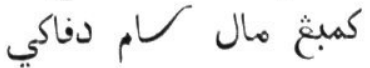

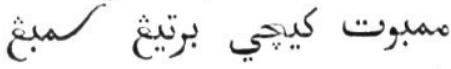
يار تيدق دافتس دهوبث هندق ماكى فادي برتعكي هندق ماتب برتنده بثكي

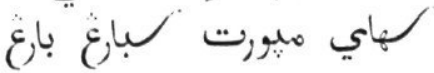
تاثٔ مهورت هاتي مغارغ
تيطان كافـ داتث مثارو روهم بسر تقكو فتري دفندع موك بروكي لروي اورغ بليب تنجغ بليكو جنجي تون تيدق بكيتر اورغ جار فولغ كجار

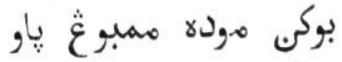
بورغ جلنتق بورغ دجار الغ هنتق فراناك. جار تمتلم فنته ائ دكأغ

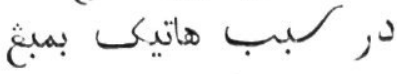


كده نصيب افنك

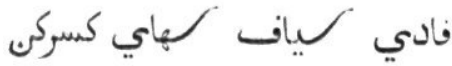

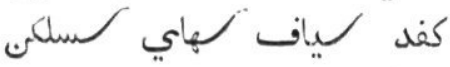

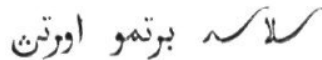

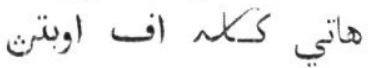

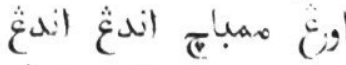

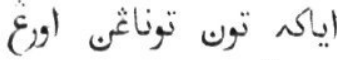

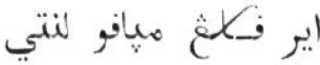

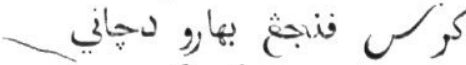

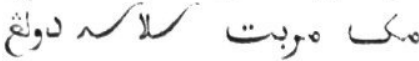

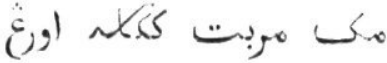

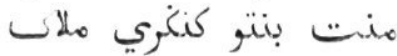

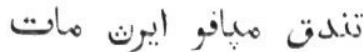

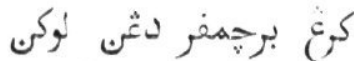
بغيتون كهاي كلهيكن تون

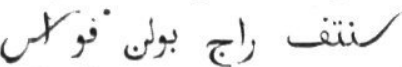

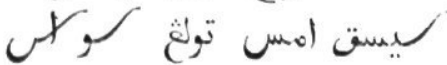
ماني توكع ماني خلاتي

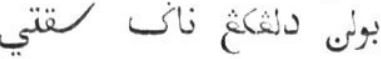

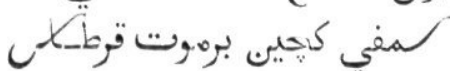
ددالم هاتي حرام تاكلفس دمعن بوع دهمفر دثر انت هاني جاثر دبري فئت تمفت همالي ايكب فاري برافـ هوكـ انته دجاري يث لروغ برايسي نانم باكي بيسل مثعكمت ناني تمفت باب مغليست بيول

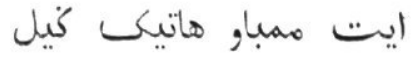
اتف بات كليست تثغيلة
كدهل دثم تقدير الله تودث لاجي ترندق بنته

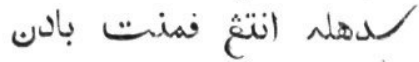
ليمو فورت لبت دفثكل هوجب. ريبت بوري دتعكل

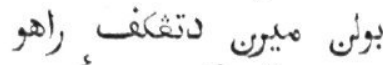
دمي اللّ كهاي تاناهو

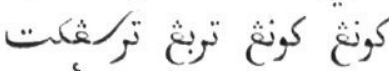

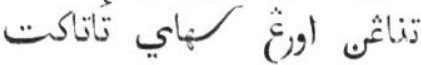
هودث اير فرباني تمبر ارع

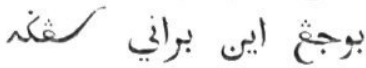

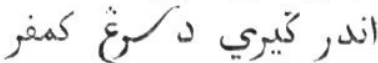
دودق برديري برتان خبير

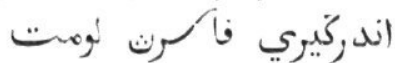

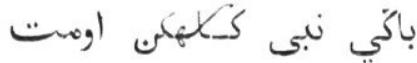

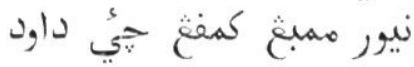
ناكت مغمبع دتغر لاوبع

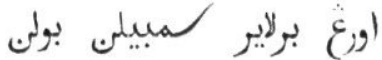
م.أنت اير كفل بولن انق هين فولع كيهن

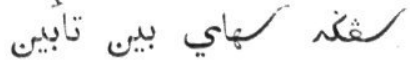

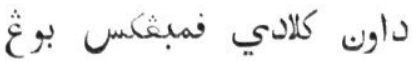
جملو لاكي تون بركون

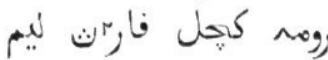
اديق كخل ابث برتات

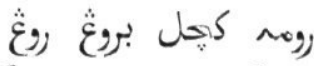

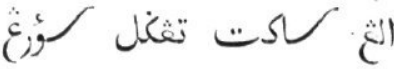

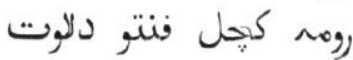

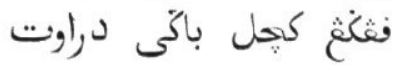
رومه بسر تقكو دهولو 


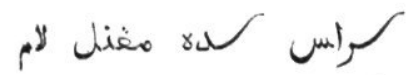

$$
\text { بوكر بلد ددالم فراهو }
$$

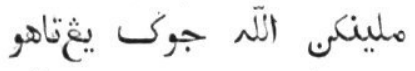

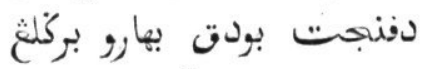

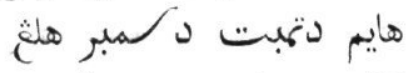
كفتت هنجمر بور فال كبرت رمبت داتس داتس كفال كيبي برلاير كفرو جرجت هاتي ددالم باكي دروجت درجن

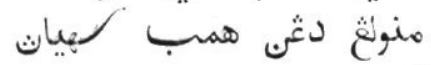

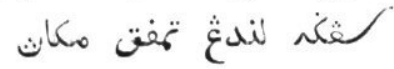
بورغ جنتايو دهلانانث همفركى لايو روف دائ داهنث بورا فكر تندنثر لدني

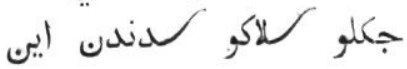
تثف منتس ايبور ماتي

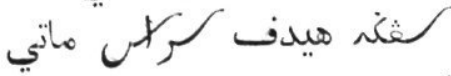

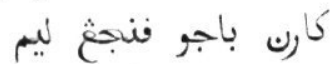

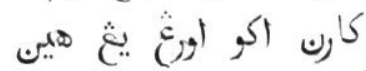

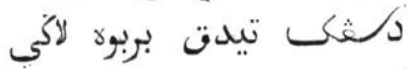

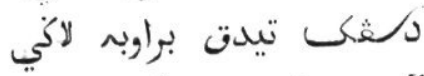

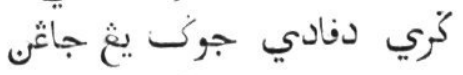
جري دهاني جوكت يث جاثن جاثن دق نقال بركائ بلد ابغ تثغال فرنته التّل دهوجت ماري دكارغ ماري ايست ماري لكارثة ماري ماري هندت ماكن دفاره جغني لماري دندق بركنتئ د داروا بسي در كريق كسيق درباي
تيدر مالم كبلق ممفي بوها فادي ددالم فيتق

تغكي هاتي باتي درنتق

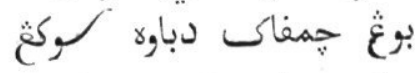
تجلى بادن تيدت بران برانتي داوب ترف داتس بوكت برك

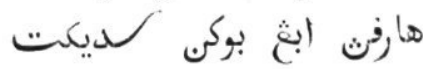
فولز فينغ نورو فنتانت برك جكلو دكنغ بودي كنئ فئن

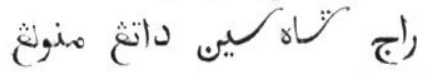

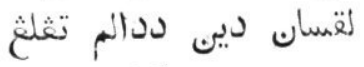
رومه ليمس كلتان يمتون

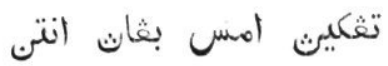

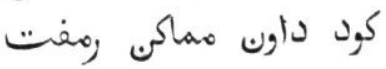
يار دبادن همفركم لوفت دون جنا

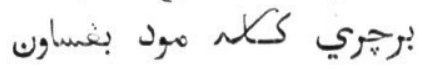

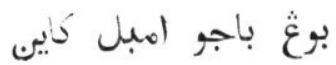
بوغكن اكو امبل يث لايل كئ

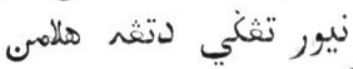

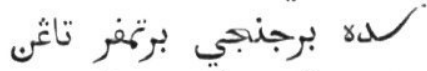

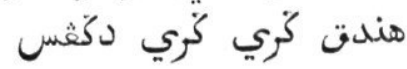

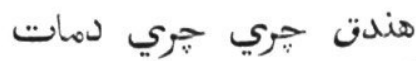

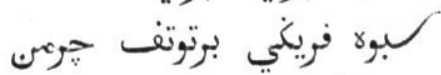

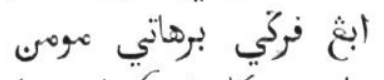

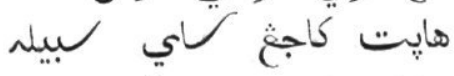
جكلر داتغ تقدير التّي انت ايكن لكيكر دمبانق

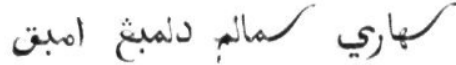
انتي بالي دبل بلد دلي 
ابغ نوكي تياد لان

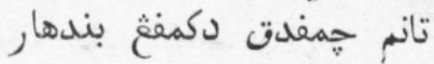

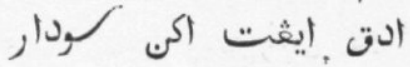

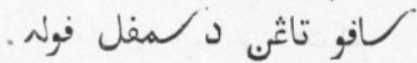
لفس دتاثم حرام تابُول حين لديكت تيدت غملي اورغ بركال ددالم فراهو

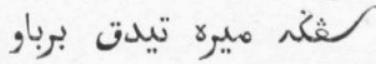

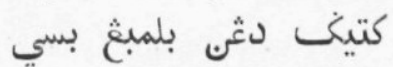
انيكى فولت دندع فريكي برجمف بور لغست لفيكي

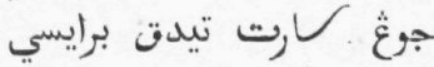
تمفيس حمغ لمني كتعـ لامب هندق برقبور دتافق تاثم إثب تهبل اورغ ايرتير هليلغ مالو كارت نخون فـلمر ملنتق فاك, لقسان تقصر كفل اكر فرك لياف حاكف مغارغ دي ليافس حاكفـ ملأرغ دي تمفت ادوغ ملمبع اديق تثكل دندم تأتيدر باتو دجورغ بله فثسان

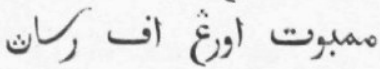
فوهن. كدارغ برتارت مود اوع

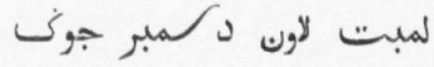

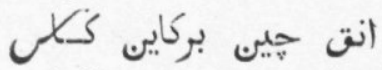

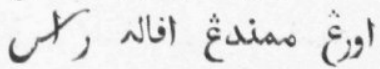

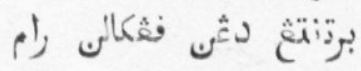

بور هاتي تثغللم توب

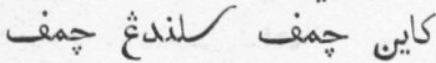
ادت لوفـ ابثفون لوفت في

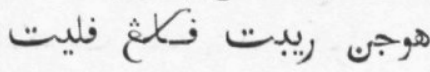
اورغ هيدف جاثَ دحيت فاي ددارت دروثي تيمت تون لقساب اير دمينم هغ لقسمان مودت برباب

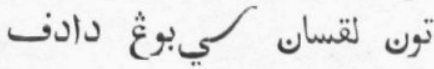
بوه كنندغ بوه كدهبق لاكي بول لاكي درهفت فركي كهوتى مغنمبل روتى لاكي جاعنله تون هارفـ هرافن

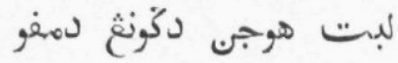
هندق ماتي دهوجوغ كوكر لمففت جواده لاد منتي هاتي برايكت كفل دي لايغ لايغ دفنتر راج لرئ

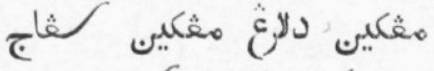

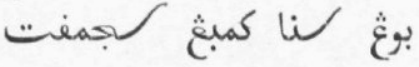
اورغ يث نولث داتع مناجمفت تغكي بوكت كونغ لنغ ابغ فركي دندم تأماكي كايو كباتق كايو دراكت فندي فول برهاتي لكتي ريث ريث بربوثي ماثم فنتت هلغ دثب هايم برئ أمبل لعيس كوفسك نانس لاك مسكيس تيدق برامس

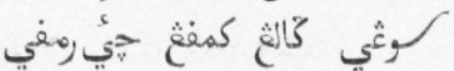


برجريله بادب دثر هار

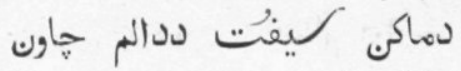

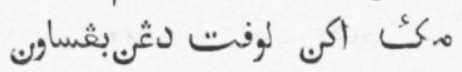

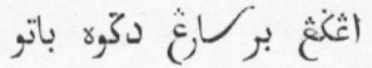

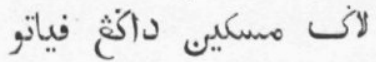

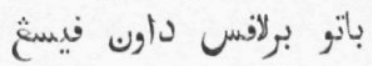

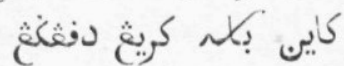

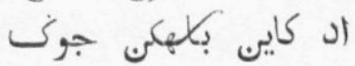

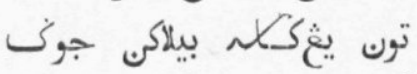

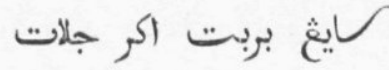

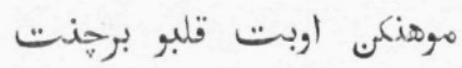

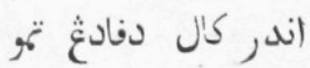

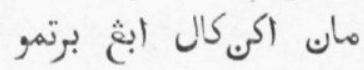

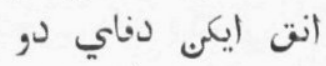

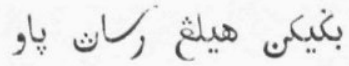

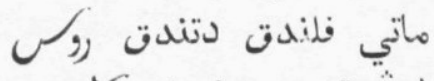

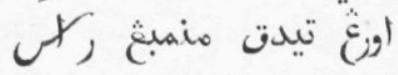
تدها تنغ رنتو كفايث

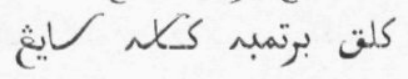
هبيق اد بربولي برئي ايت برنام دنيا كيتي

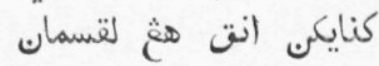
كفل ابغ تيدت كمان

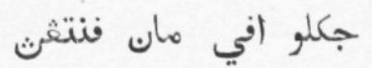

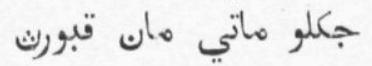
انت هودث دنسلي مائ مايث

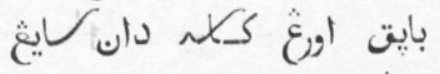
اورغ برجودي داتس ورعبت هوتغ بودي هاتي ترايكت تمفت در جوده لام

بوكنث موده داكث د ليت

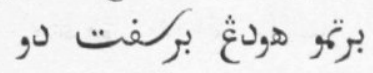
بوجريله بادن دثر يار. دوبلس كونغ دنكري فتاني

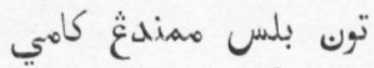
الغخغ برلأع دكوه باتو لاكت مسكيب داكعة فياتو الهبل راهت دهب در هولي داكي

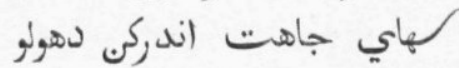
تمبه مهفلم دكمفع هيب

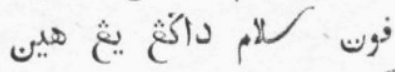

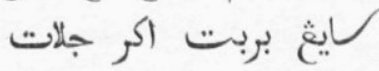

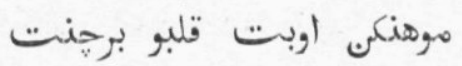
بوع تنجث ددالم كوثم تيدت ترتغفع هاتي ددالم

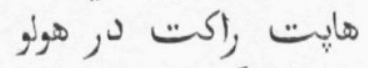

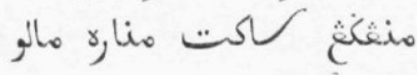

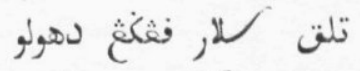

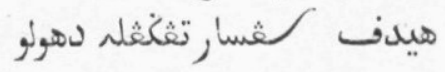
هلير راكت باتو تثغلم

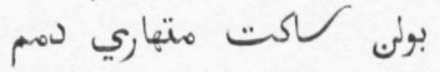
كود فوت فلان هيتم ابث نوته ادت فون هيتم

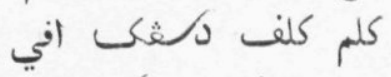

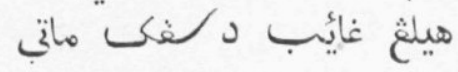
تثغلم باتو تمبل كلف بوثله اكو تيدت مثات تمبل كلف

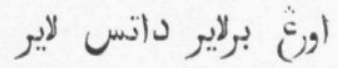

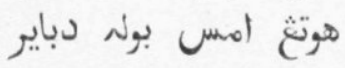

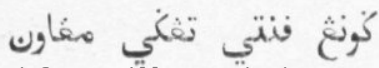


مكت تاكمار مثهادف دولي

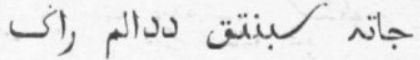

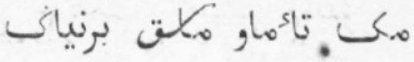
فهى دتفف تودث فتي

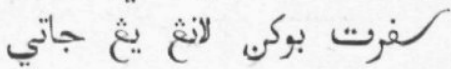
لده برتلر دتغخلكى

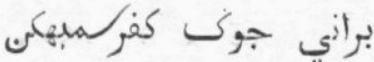

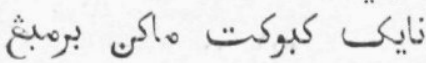

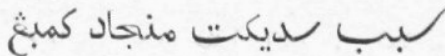
دامبل دلتق داتس تيلم

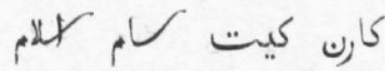
هثكف دجله كايو بردوري دكاث. انده تيدق تربلي كفايغ تهب دالم دوبع لايث "لثمد يوانث هيلث ، بورغ مرفاتي تربع لكاون باكي بوكث راج فهلأون بور بيدار دمبر في فيفت

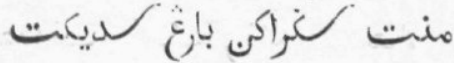
ممفي كفادغ لال برهنتي فلدوكس ادند حضر منتني بلم كده بهارو دفاكي ليره كريث فينغ كوتي

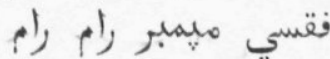
نسليث عمبر لاوقث كمعما كئ رندي ددالم فوان مكس بوائي تيدت برلّون بوثُ دئم ددالم نوان

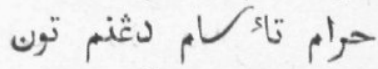

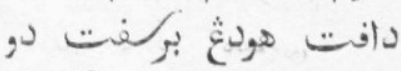

كورغ بهل كراثُ تون هنيحت بيدوري ددالم فولب بوكى جوهري روفاث تون

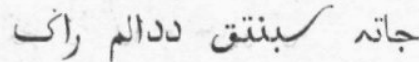

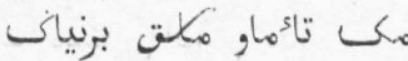
انت اثكث دهوجث داهت جكلو تيدق جاد كمركين هويمو د لبوغ دهولمونث هريمو كارغ دهولونث تبو لفغكن ددالم فادي لاثت كن كفر هاتي

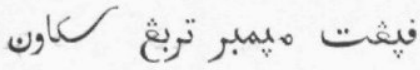
لاعتلم هابر روفاثن تون هغكتف دجله كايو بردوري دكاثم أنده تيدق تربلي كفايث تهب دكايو جاتي لفرت بوكن. لانغ يثجاتي جك روبر كوت باتو جكس لمبر فازكس بولاكو بور بيدار د مبر فيفت

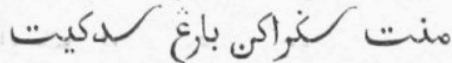
كاير بروبجي داتس اتنـ

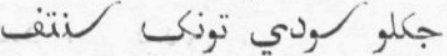
داون مaفلس داتس اتنف

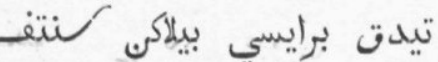
بوه دليم ددالم لمثكو اصل كسؤم دولي تونكس تنت بول امل كفين كاين

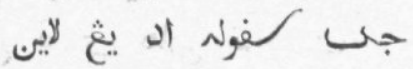
دثع جده دودق منامجريت 
بوغ درهبت لهاج دفر/iنع هندق همبوت تثكي كثكات مارهكى (وزغ تيدق برجاله تيتين اوزغ فركي كرمبـ

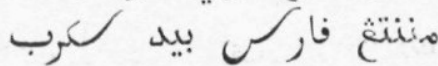
انت عرفاتي دماكن كود رهقلم ماتي دثر ادن اند تاره فافن در جار

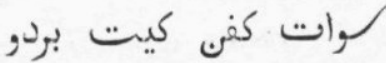
بوه روكم در هيم مانكم توجاثم ترولنجر بيث

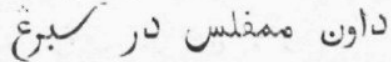

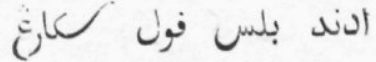
انق كرود هـك كون كون كنيد كز كر فول اكي دفاجو, لنتس كدالم اون. مونكم بلس فل بثمساون جاثُ دكرت دثر تالي جاثُ دجرت لعالي كاي ايكن داوفس دثن. برأث. انتت تروفس درفد تاثر انت كوتث در بنتت درد

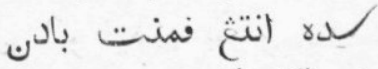

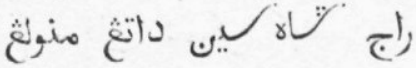
لقسان ديث ددالم تثلع اورغ بولمبو دموار

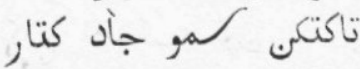
فقسي اودر تربغ كهولو كس لعنس هثغف دفوه. كند كولي
لمفيث هاتي دولي توزكس

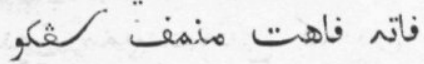

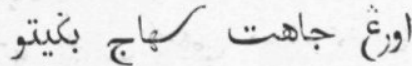
باتغ لوبت تهب حنداون

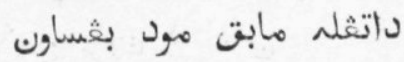

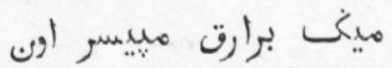
كکند بروره دثنم تون انت مهفاتي دماكث كود رهقله ماتي دثر ادند ايتق تربغ كدالم اوت إن

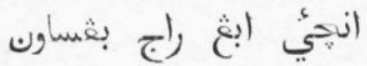
بوه روكم در جئب مانكم توجاثر ترونبر بيث

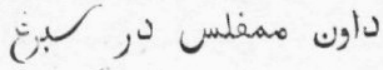

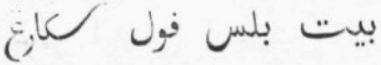
كود مهابيرو بتار, كسن.

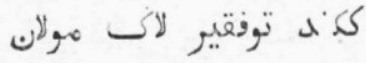

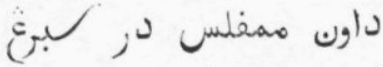
كمينن اغخس فرهائ اوزغ در بولغ تورن كفنتي دمبت بورغ لال دفاكي. كوت دتلق دثر جمباء. دمفلق اوزع برفنجاثٔ.

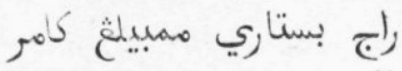

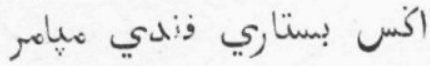

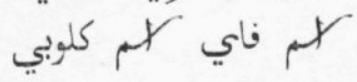
افاتم دايي دثنت بوني أورغ جولمبو دموار تاكت لمو جاد كتار فتسي اغخنس تربغ لماون 
مله

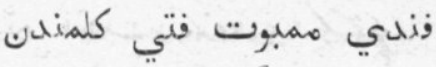

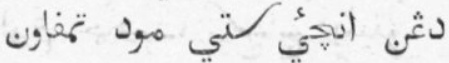

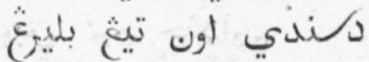

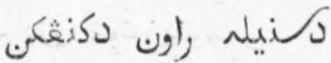
جاتم كتلت كحله باتو انيكن. فول جاله يثي تنتو

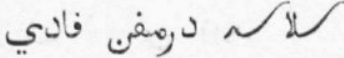

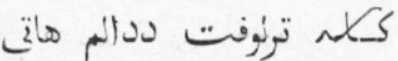
بودزي جوكَ اكث لورهن

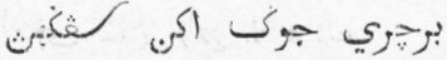
كى توجب لال ماتح

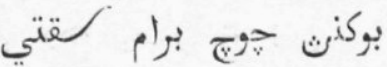
أنق لمبو ماتح دتهبق انتم بوتمو انتهك. تيدق ماتج كمبع داتس كوتي

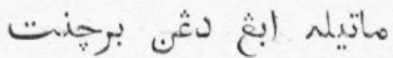

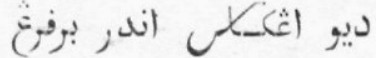

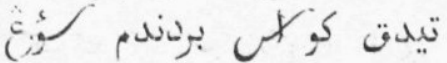
بله هاون دثب كکئ بادنكس تون افن جديث

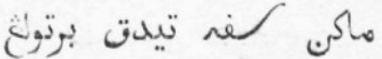

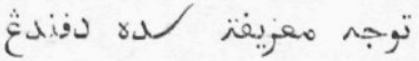

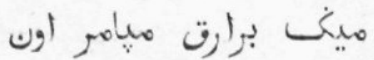
كوات كف. كيتسن. تون هثكُف دبوني كيو هندان بايكا نركي بارغ كملن بور فاني داتس برند برن

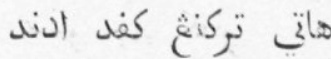

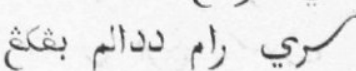

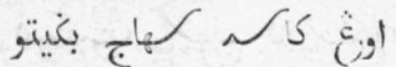
توكث جاو, راجاث كده

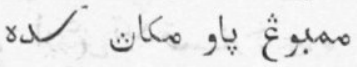

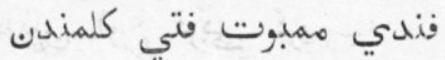
دثر اذهيء ليتي مودتمفاون

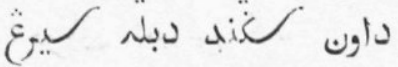

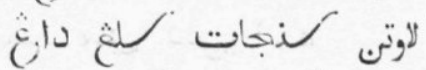
رهبي لهوفت ملكت مركم تيكس تافت توب ملفكم

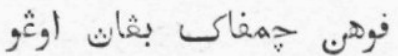
كنلد ادند جاثنلم جمو بودت بودت جبوهايي باتو

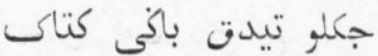

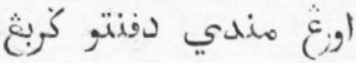
جكس كمبالي كراغث ابث أنق لمبو مانت دتمبت انتم برتمو أنتهك تيدق

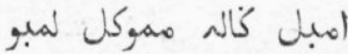
التّ وي المبل يار همبام جكلو كلورت فاديكس ائي جملو كتورت هاتيكس ائ دوري هُ لقسملن دودق دفنتر بكملب اكو تيدق بكنيتر بوزغ مرفاتي دهاكث كود

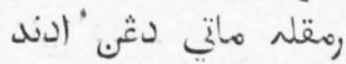
كونغ كونغ تربث كماث كاون

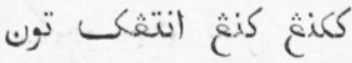
لقسمان ملارق دورغ بكماث تيدقك فورغ بور فادي داتس بثكو 
جكلو هندق مولتث مانس

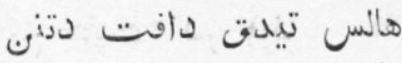

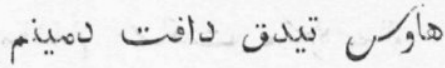

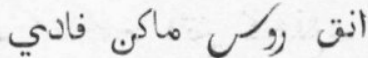
تمفت ابع بركندر هاتي

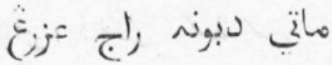

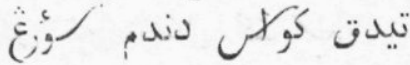
هلغ ملات ددالم فئنس

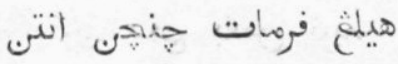

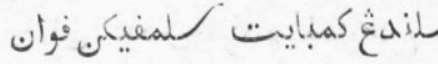

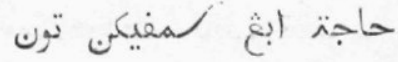

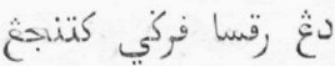

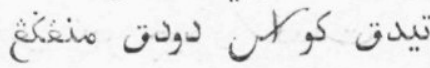

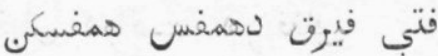

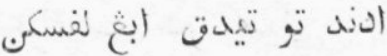

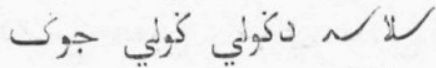
يث كکكه دبلي جونت

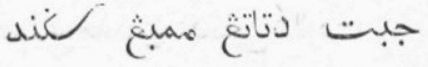
عادت مكانت اورغ يثمود

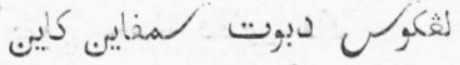

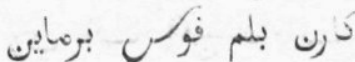

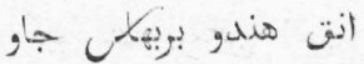

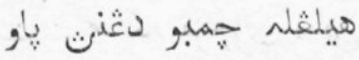
فاته كالى درهفون

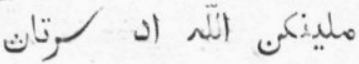

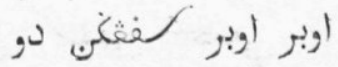

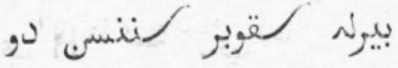
أنق جياين فانه تثكتي جكلو كن دثث تمختن توكث جاو راجان كده
لاكت لاك كل كانج همبوهُ

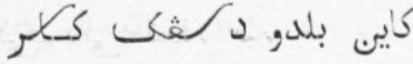

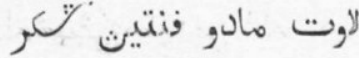
روبي لنتي تيتين كيبث توبي كيجل دداث بيدئ فدوك ديو كمبر كلتي درفن هيدف بايكيد عاتي

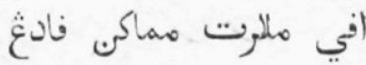

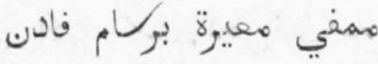

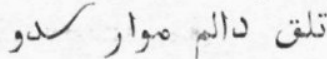

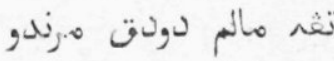

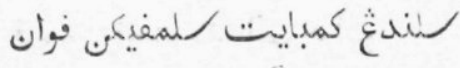

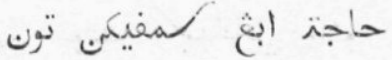
كرت روتن لبارة بنت تبن

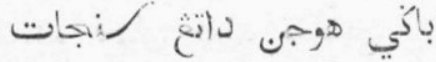
كاجه لكور كود برقس دانس

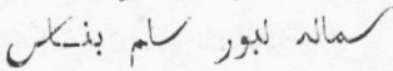

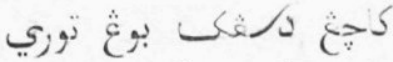

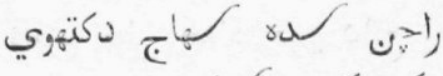

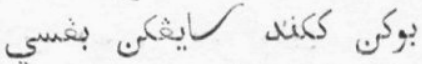
بوكن كند كلد لكائكن ماتح

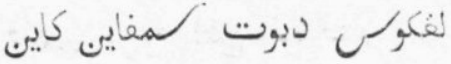
بلم لاك فورن برمايي

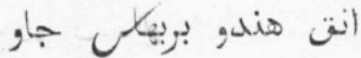

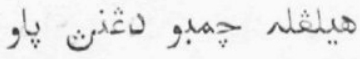
فاته كالم دمرهنوت

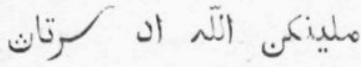

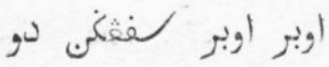

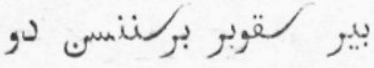

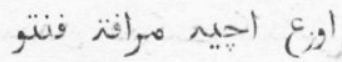




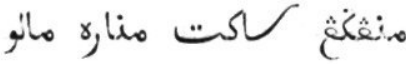

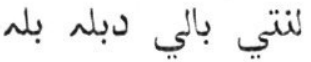

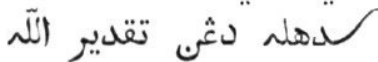
داهم رتل بوتكن تالي اكث بكل ابث كمبالي تالم فسق دتيكم فاري مالم ايست ابث كماري $\sim$ Sllo

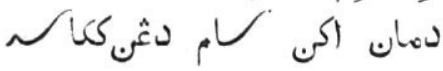
تمو ترهنتر دبوت رهن ريفي برتمو لبنتر باكي برمهني فيسو راوت ددالم فراهو اجلث موتت كبافكن تاهو

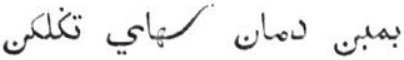

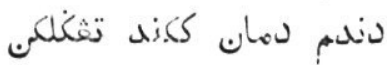
انق كلغ در دمانع

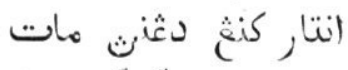

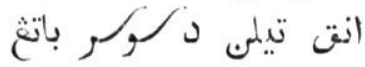
كلفث بوله كناند فوت داتع لندق بومايبه تلر تودت هis فندل بربوه اكث. فرمات ماكث بركومكن اليومات

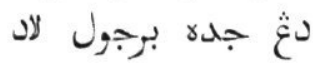
عشت براهي ددالم داد دهود

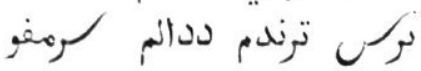

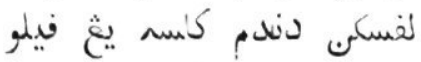
تنجع جابع نكري لام

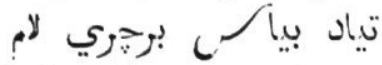

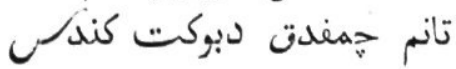

ملينكم التَ جوكـ يث تاهو

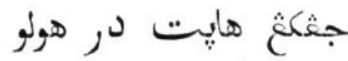
مانعظغ

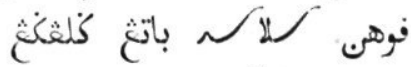

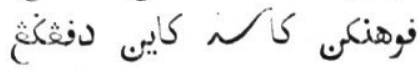
فغكل فوان فثكل فيكل تثكل تون تغكل كساب راكت فافن برايسي بونر لغنهفون كفن بكس توبي حران بيدق رندم لغكور

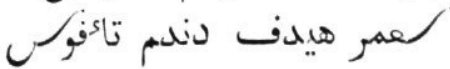
تتق اكر كلثغع دبوكت

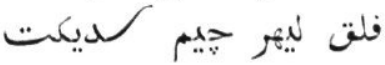

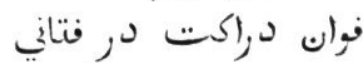

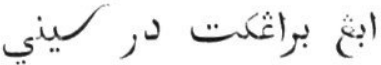

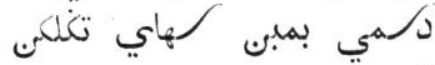

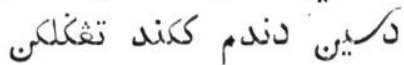
تانم حمفلدق دتفي لارت

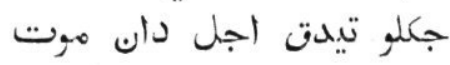
بمب. حهما دفاي فاكو

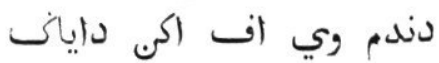

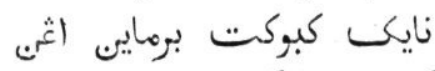

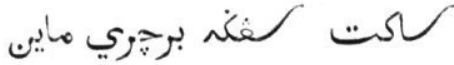
بايت كاجم دتفي فسار وي اللّم تنجقكم بهار در بالي كمفي كجمبي يالني توهذك لِّي لِّي تلق دالم موار تلمدي تقم مالم دودق مرندو فادي مود ددالم كرغ 
دبار تيدر تياد هندرا

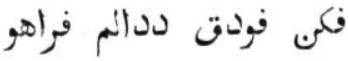

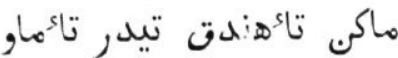

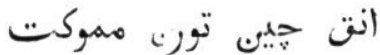

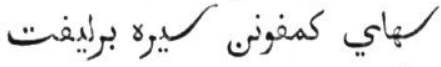
اوزغ مaبكر ايكن فلاتي

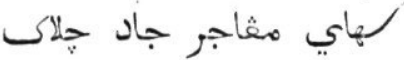
اثكف اغُف تربث كجين

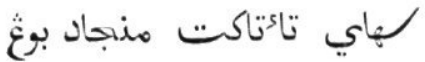
تمو اد دفثكل لاد

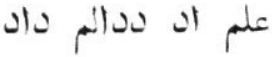
راديث اينو تورن ممكي دوالم داد

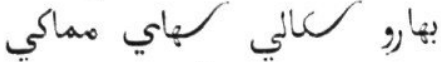

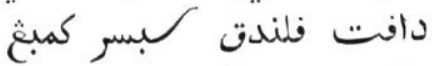

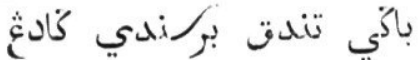

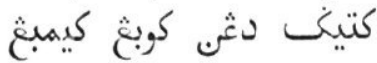
بايكله كهاي كمبالي فورلغ

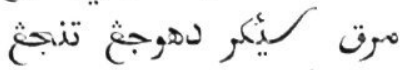

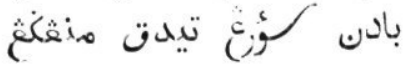

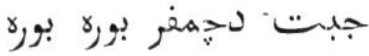

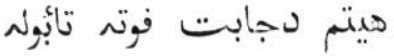

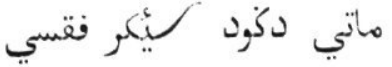

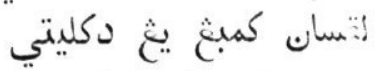
تربغ هلغ داتس كوت كلغ دكين

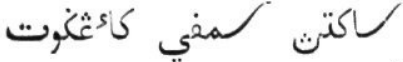
برك فادي ددانم فيتق ركانث هاتي باكي درنت دونت باتو بله ددالم فراهو

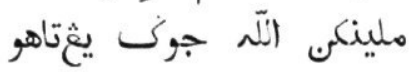
جثَع هايت دين در هولو
لكتث تونث دندم تركمبوبي

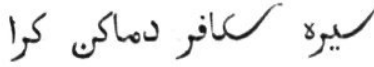
تباز تيدر تياد هندرا

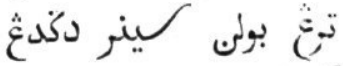

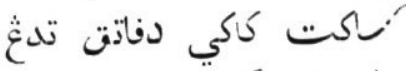

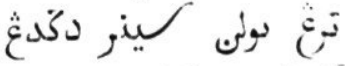
كل كت كاكي دفاتق تلث

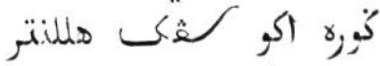

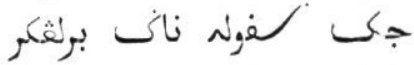
اغكف اغكف تربث كيثين

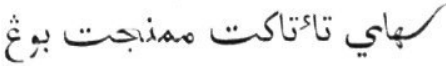
تمو اد دفقكل للاد علم اد ددالم داد داد

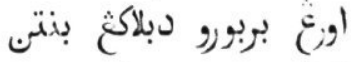

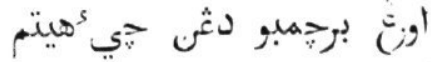

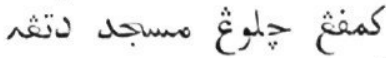

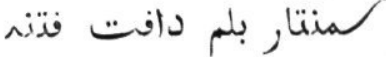

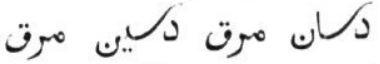

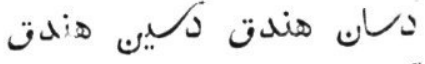
لافو تاثن فيافو تاثن كيل تاثث جلاكس تاثن تربع كرندت دو كات كلاتون

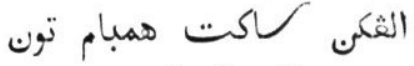
هـتي دكون كئيكر فقتي

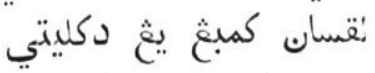

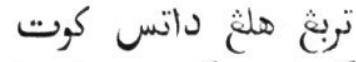

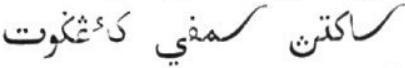
برك فادي ددالم فيتق

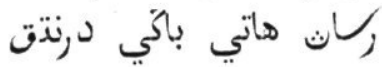
ناتو بله ددالم فرهو 


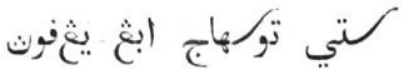
لاد مود ددالم فوان

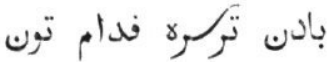

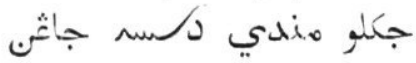

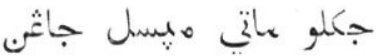
كتينت دثر هي هندق فرغ كن كنيا

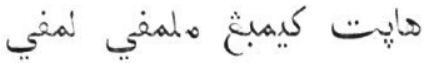

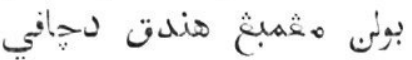
لوحتِ داتس بوكت فتري بورق تيدق بركنتي لاكي

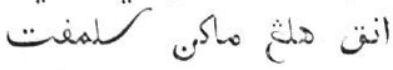
اخيورت ماتي تيدق بركمنفت

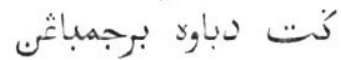
برولف هاتي برفناجاثم. دون.

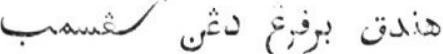

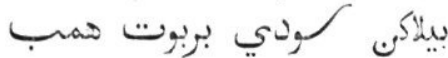
كندر دفيلغ راج بالي

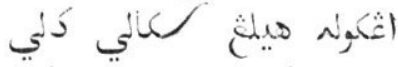

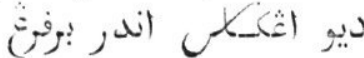

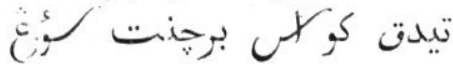

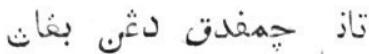
هيدنـ فونتيدق افـ كناني دانبل بودق برلازي لاري اثكرن تيدق لعاني كَني ماري دكتم فاترهل دي جمنو تيدق افكي داكي دلي دان

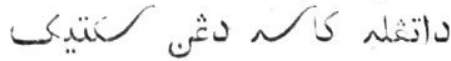

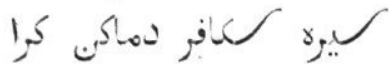

دادن تركره كفدام تون بوع رهني فندق دباتو

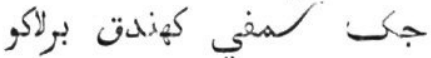
كينب ايين كنيب در جده مايث ائب مائب فيوده

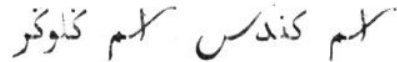
دودق هناثس دفنتو قبور تياد نيل بوتكى نيل ملن تياد كيل مهبوت كيل نكوي ترغكانو بوكوت فيت فافن تون لقساب كئب كن. كوث تيج ماكر فديكـ جكس بكنيف رد هاتيكس

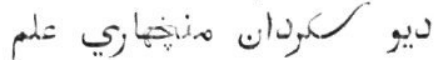
ايو دي بادن افـ انتعثم

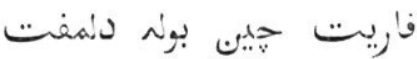
ككند هيث تيدق برتمفت بوك فاكو تندنث

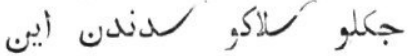
كيو كُالم فثهانو لمبو أنّ وي دمبل يار همبام اوزغ فثهيلغ دفانغ كوجان

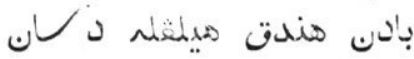

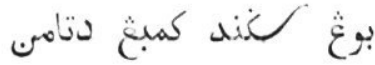
درفد اد بايكله جاثر برتانم اوبي فادي لـنيتق كَرث بوني هاتي ترلتق كلطان فثيرن ادي في داتي

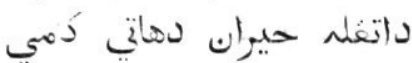
بودق بندن فندي بريابي 


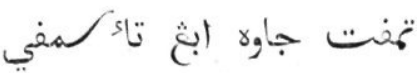

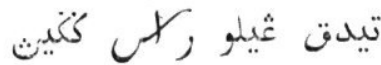

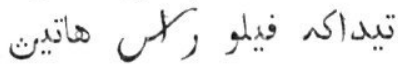
تجب دفارت رقنا وابي

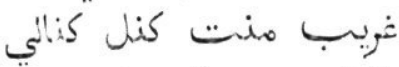

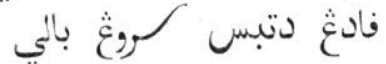

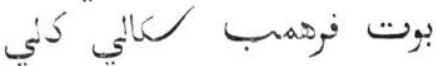

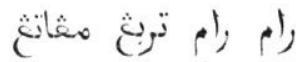

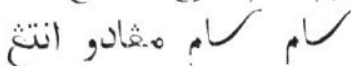
جاث تربله باتث هيدف

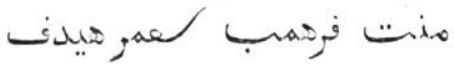

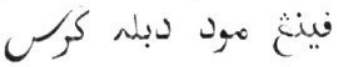

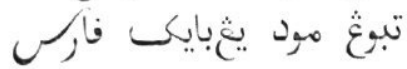

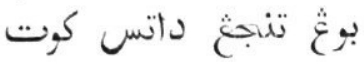

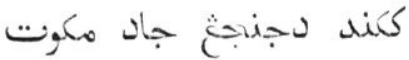

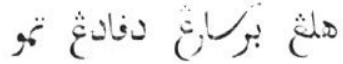

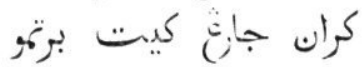

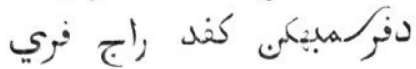
اندهن تيان لاكت ترفري

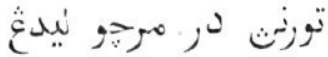

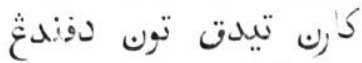

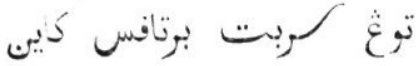

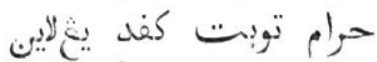
اهبل فلتى بوبر كيحاون

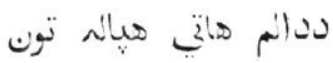
دع بيكو مهمكو فران مهرهك ديري فدام تون فئر رندم فره دنالم فوان

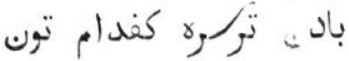
لندي كَّ ددالم هران
رندو بزر ربل هاتيكس انت بواي براونم فاوه

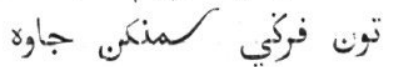
بور همفلم تمبه دفارت

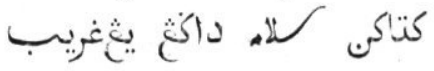

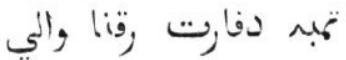

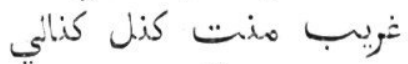

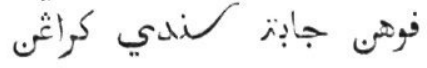

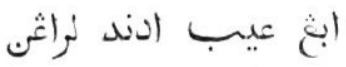
بله باتغ فننجار بابي التي لمام داتغ كمبر "كمبالي

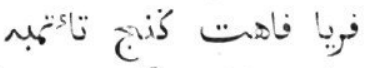

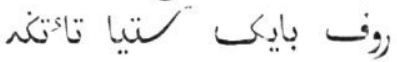
أوب دراكم اولم دعجده تونيم مانكم ترلالو انده درد

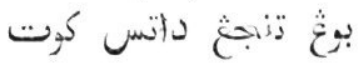

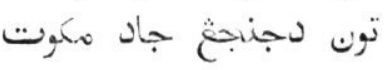
بلي دباثث اندر كياثم

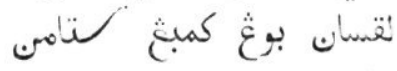

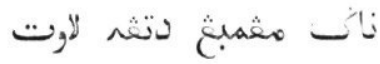

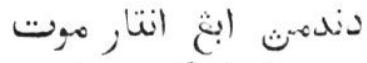

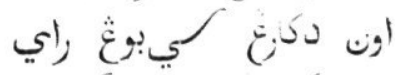

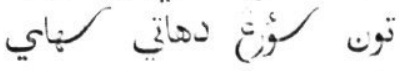

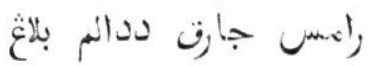
أهس دان في فيرت هابسله فان

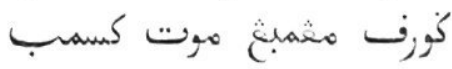

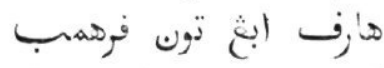

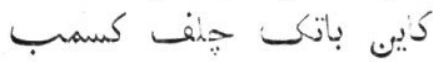

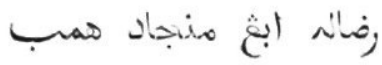

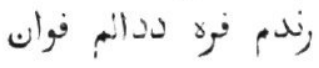


هابس جنجي مكاث لوف رأف هاري دنتك رابت رادن كاله هاتي ددالم هنيجر لوني باتو كليك ددالم فوان ماريله دريب ددألم فقكون فيك

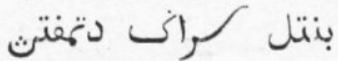

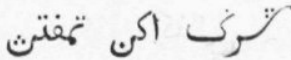
جاته كتـلت كاكندر كئري ايو هي كسا لم همبوغ ديري انق فيني ددالم كراهي

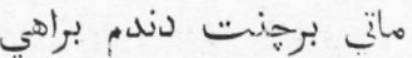
حِين هندي اير ترجن تيدت كفقكس بوغ دكبي لهاج كمندي اير ترجن

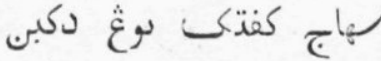
هلون هنوجر ككرت كري نفسو ايت لاوب برفرغ

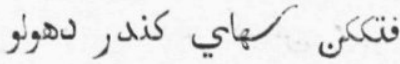
بير لهاي اندركى دهولو

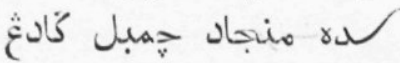

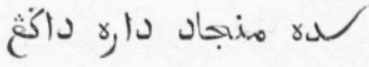
هايت كيمبع برجاري جاري

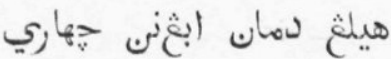

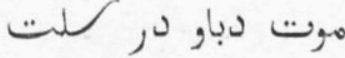

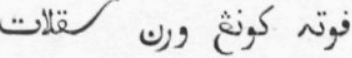

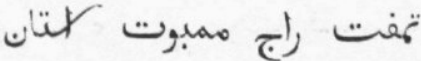
دبار هاتي كنده كلان تمفت الورغ برتانم فاوه هندل لديكت تمفتت جزور،

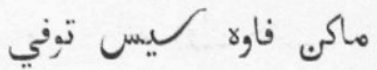
Be volgr. III,

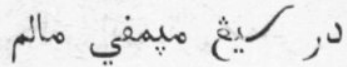
بوغ نيلم كمبع لايو رندو دندم تاهنكب دهولو نئم

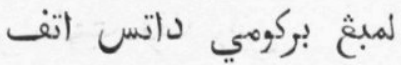

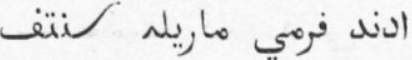
باتو كليك دن دالم فرأب

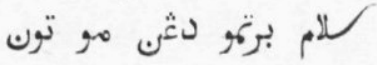
هلغ دمبر راج والي

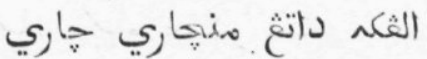

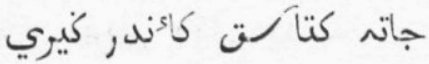
جكلو تيدت داتع هن هـهباري مالم ائ مالم جمعت كيدات

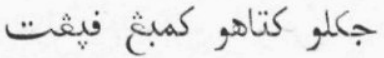

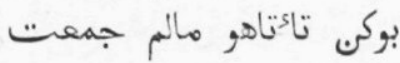

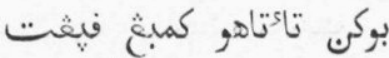

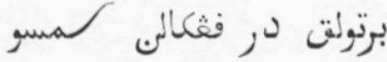

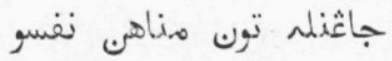

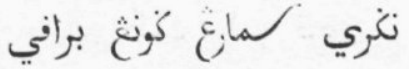
تيدت ملانغ تون براني

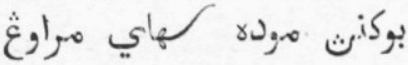
بوكنث مودها ابث ممبورغ

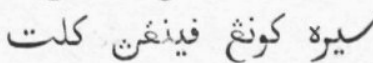

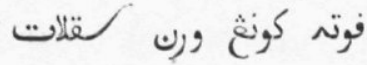
رومه ليمس برنند غ موت

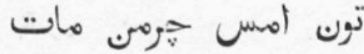

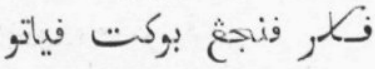
دودت بمبع هاتي تاكتنتر

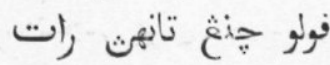

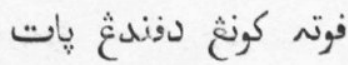

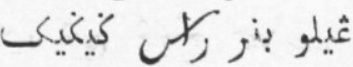


IETS OVER DE PANTONS DER MALEIJERS.

330

ابع رندو اكث بغُساون

بيل كال برتمو تون

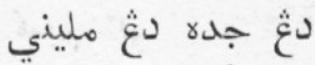

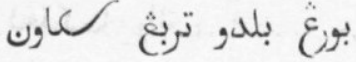

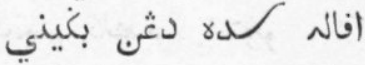
فيائ انت دار دعبيكو ماريله فوتم كنائ فثكو

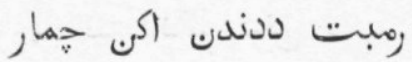

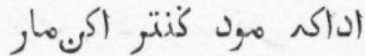
تمفت در بوكت هئ اجبي ابع تيدق منكركى جنجي مادو, كلوفت ددالم فوأب ركــ ابغ لفاك. تون

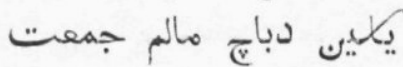

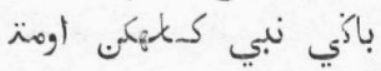
فربمباهن انت رأج فرهفون بادن تركره فدامب تون هثكُف دفاكر ليني ديوي بيرز ابث هنارق ديري هندق مثڤهادف برام افت كهندت ددالم هاتي

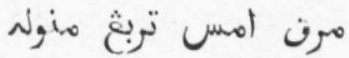

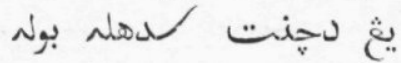
ماك لت بلوكر فاتر كادثرث ددالم دنيا كوكر بندثرث ترهمبر هنيه در در جاري لليـ درفه كهاري هاري أي كتيتر فرغ دارون

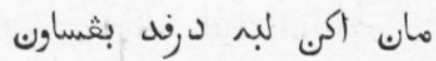

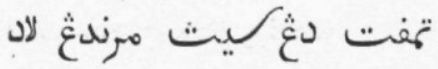
تون جوكت جمباءث مات

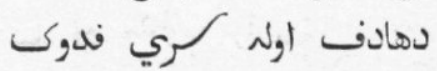

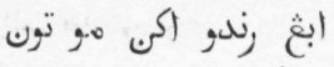

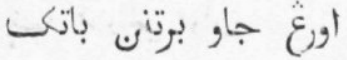

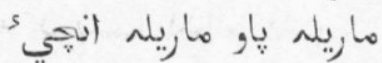
وريسي يث برتالي رهبت نباتي اداكى بيسي تهوكى تاكي ترثي

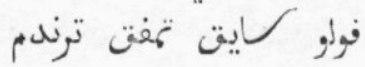
جاثث تون برهاتي دندم

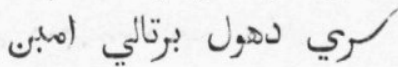
برحري باجيو دثر كئ دئ فويسوري مهبله يليهن

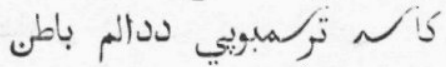
اير ماور لهيبق باتل در اول لمفي كائر

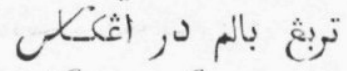

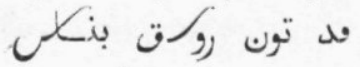
مرت اهس بوز) ديوات رقن المس فسف جويت امنس هندق هعهادف برام لعتي افت كهندت ددالم هاتي كاجم هين دلاوتن جاو ايو هي ادند توزكس هار رادن كالم دودق هيمبر لغغنم تيدت للاكو براوبي

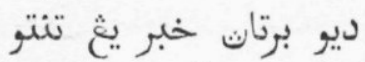

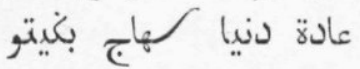
ددالم كوت فنتو كربغ

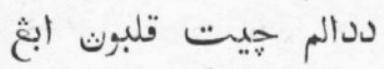

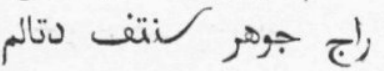




\section{بروت هاتح برفنجاثُ}

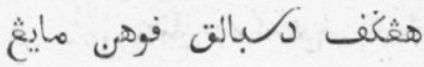

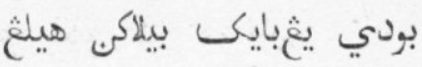

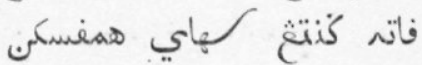

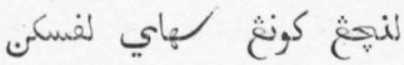

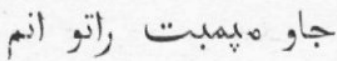

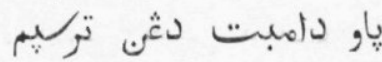

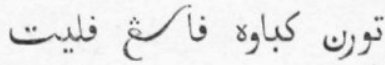

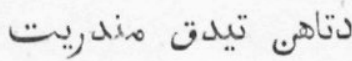
فاته ترجاته كدالم كولم

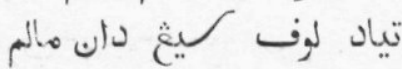
لاد كولم تمبر دفاي هندت داهبل تياد أوفايي

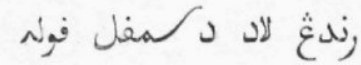
هاندت دبار تياد بولم دئل

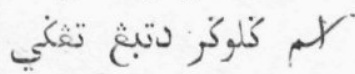

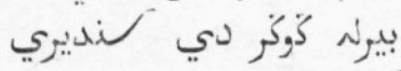
ليكوديدي مناني دفي دينتي اولر ماتي بوغ دفاكي

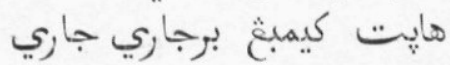

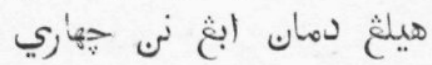
داون بارو ددالم فادي بهروي دافت بارن دانمي دهاتي

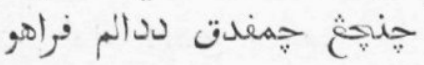
تيدر تاكهندت ماكى تاكمار

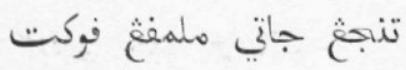
بوه هاتج ماريله دكت فاتج تمو ددانم فوان ادند كستي ماريله تون

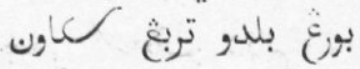

افائ لده دثم بخيني جنتايو بورغ جنتايو بوغ كمبع لهجاكن لايو

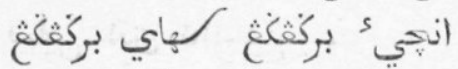

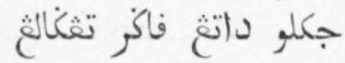
فادي دتلق فاكرث كند دان

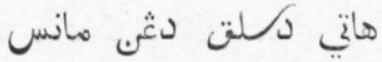

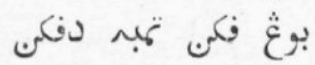
هيبر تيدق ترهيبركى

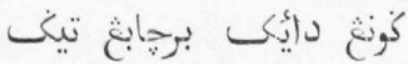

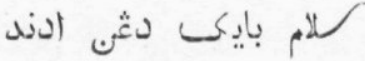
دودت برجاله ددالم تامس دون اد لكات ابث بركنت

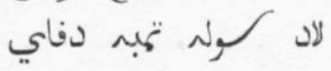
هندت دامبل تياد ارفاي

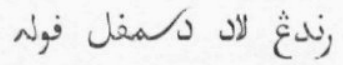
دفندع أد داهبل تاكبون دئل

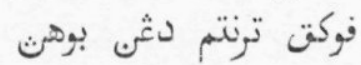
جكلو اد انتع توهث تونث ليره كونغ فينغث كلت تلت فوتم كونث ورك كقن فينات كلت

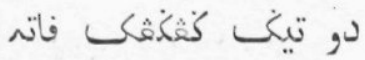

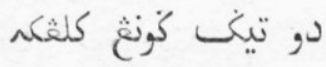

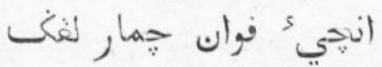

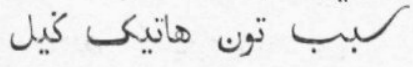
در ملاك مودت بونته

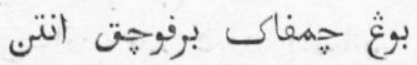

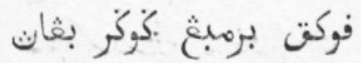

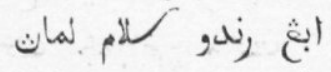
فاتي تمو ددالم فوان 


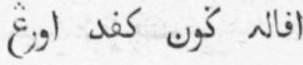

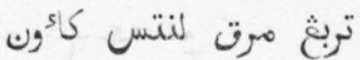

ابغ تيدت مثادف ترن تون كرن

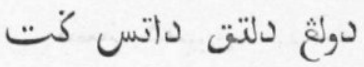

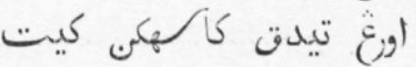
تبو دبلوكر دماكى بابي

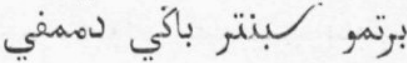

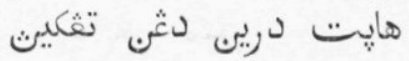
ننتي كمديث الد بالسث

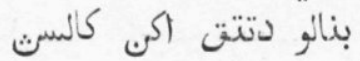
كواتفون تيدت فمبالسمث

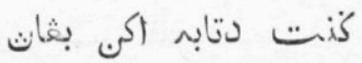

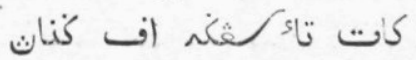
اورغ براكت بومبوت كود

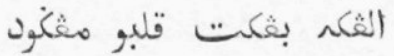

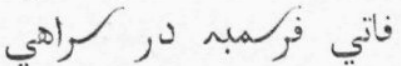
هاتي مراجت فربي تمبر براهي فركي بركود فولغ برلمبو تهبر

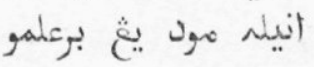
بركنيجي أمس برنتي بسي ترني كنتي ترذضر اد دئيسي

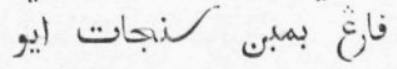
هاري هوجن رهفتث لايو

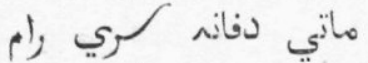
اصل تون اد برلمانم

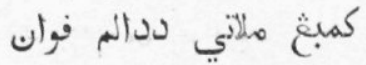

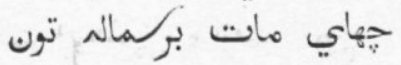

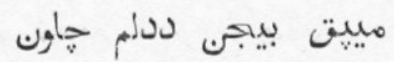

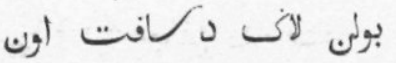
مكلق فادي كجمباثن
لاكس هيب بثس تاكتنتو

المبع الار صليح كميداب

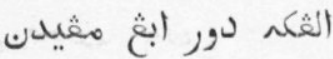

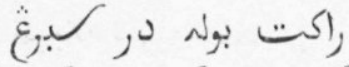

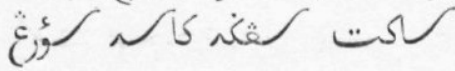
جمفاك راي ددالم فادي افاته داي دثنثم بودي

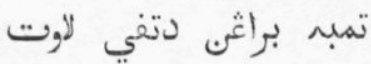
كرني تون ابث ملمبـت

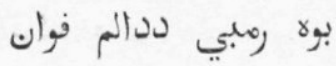
المفر كرني دلي موتون دوالم ريك انتلس تفي براون جك انس بلسم تون ترانتع باتغ كايو مرنتي جك دتنتع دمات هاتي راج ابسه فركي كتلت تياد أرم مود برتاجق في فيتق داهن برأث بنتق فراهي ادنل جاثن تياد تاهو

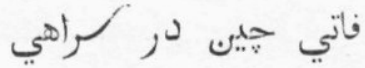
هاتي مراب تمبر براهي

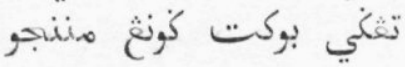
هاري فانس رمفتث هيجي

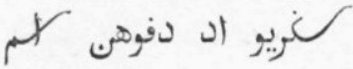
بيرث جيو ككند فادم

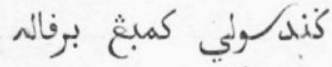

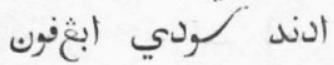
كلادي اير تمبر داير

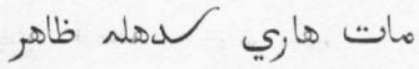
دم جدها دع ملينب 


$$
\begin{aligned}
& \text { برجري جوكت كيتنم جاثر } \\
& \text { تعلث درومه لقسمان } \\
& \text { اد انتع تيدق كمان } \\
& \text { روي تمبه دترمبو } \\
& \text { كله برجوي فول برتمو }
\end{aligned}
$$

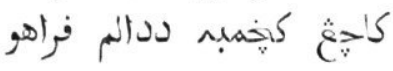

$$
\begin{aligned}
& \text { توكر تمبر ابغ تاكمار } \\
& \text { در جرت كجراتي } \\
& \text { در مات تورن كنياتي } \\
& \text { لاعسمان توكث صفتث } \\
& \text { اصل كث دث. تمغتت. }
\end{aligned}
$$

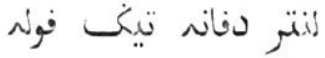

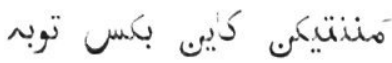

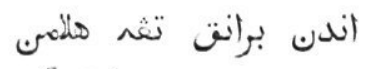

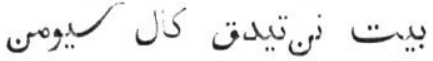

$$
\text { انق كمبع برتالي تاني }
$$

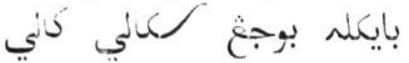

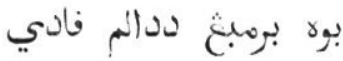

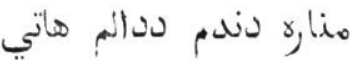
بهارو دتبع دمبلمكك.

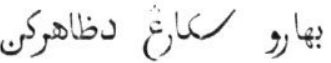
كريت برتبري اكك بلدو بيت ممباير هوتغ دهوبر برئ هاون دلارق تاتث فوهائت

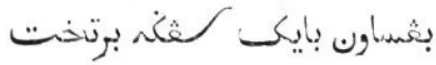

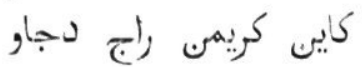

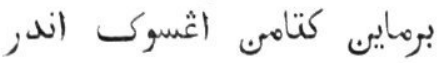
كنتم دتامس فعليفر لارئر

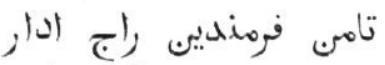

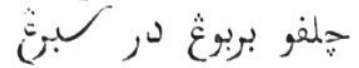

بانغ افت بير دتورت ديث دو فليت دو دير ديم جبوكت صبركن جوكت حنداون تمبي داون

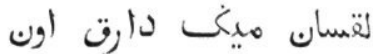
فوجق لـيره مهتكس فينغ

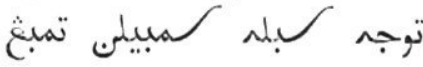

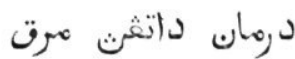

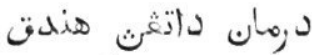

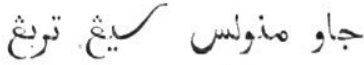

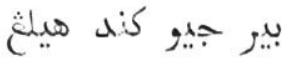
لتسمان بمانم

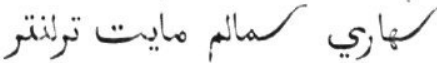
فتسي ويلمان تربث كهونو

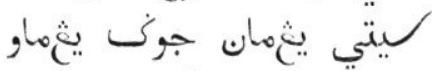

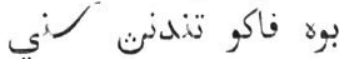

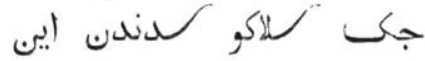

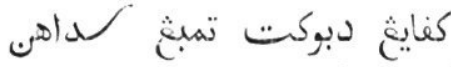

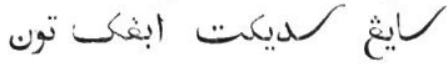
بمبع دتاره ددالم فوان

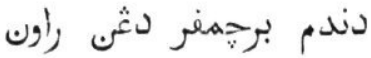

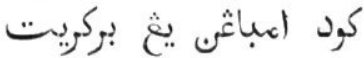

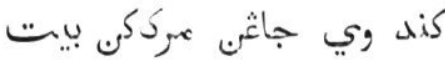

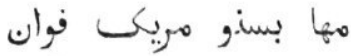

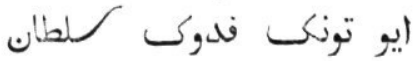

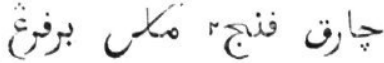
بايكس برهنتي مكوتت اوزغ كنتم دكوبـ أولم دغ كنيا

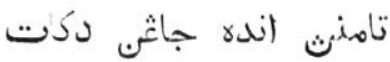
تمبر بوغ داتس باتو 
برأهيك تيدق تصندريت

بوزغ مرفاتي ماكى ددولغ

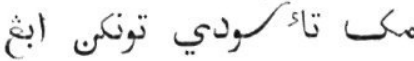

باتثرث ربم كتانم تثكي

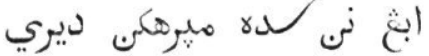

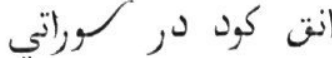

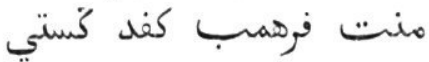

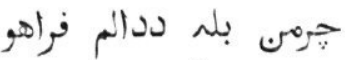

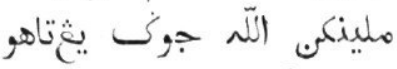
هايت "لمفي كفثعالر كمفس

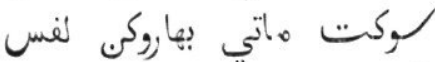
دمكت دث. كنتع ياهن. منتتع كنتم كري كياء. بثاث لوره ددالم فراهو

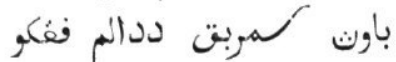

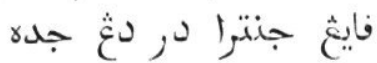
هاتي مسرة بوكنث مودها حاون كثة دفانغ كنت تون كوزن جمبائر مات مغمبل بوغ كنه فوري تيدق فرنم داتغ كماري ماني دتيتي كيهلغ مالم ماكت ماني مهفي لبيلغ مالم

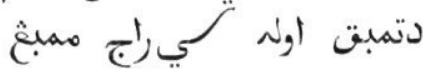
تونله اوبت هاتيكس بمبغ أنق كرود تورث هندي بكيتون كهاي مناهن هاتي

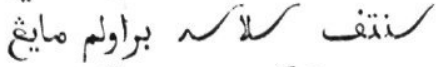

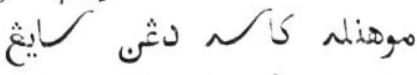

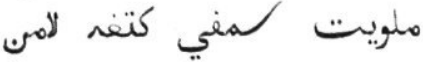

لدع مانس ابث مننتع

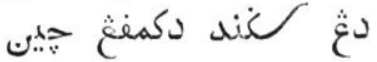
ابع اند داكث يثهين. تتق حمفندق دهيلاك. هندق فونتيدق بيت ريت رضكى تربع كرود در بنيل

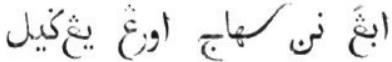
كرت لري ددالم فوإن

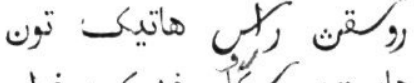

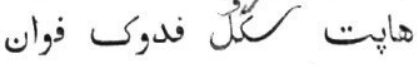
جاثٌ لـوكل هاتيم تون لقسملب هiأبغ لاد بكيمان هاتي تاء كيل

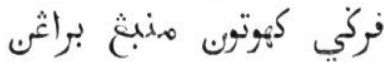
لاثتله ايلق كنتم كياث.

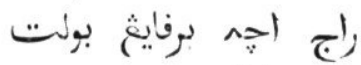

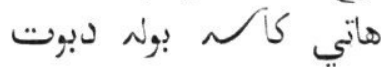
تثكي تبع دبوكت هغني دباوه لاغت اوني يث دوبي فوتي انيخ كوبت فركي كلانع اف حاجت ابع برتندع لمفتس دهوجغ باني افـ معرفت تونن. فاكي برق تغكن ماكن دورئي

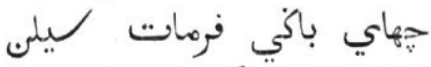
فوكل كندث

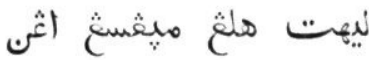
انت كود دفادث أهبت

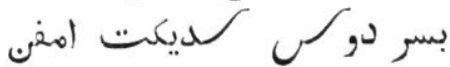

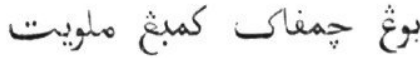


جكلو ابغ برافـ لاكت

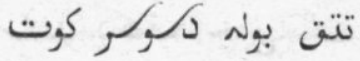
اناكى لغنم باكي دكي دكات كوت دتلن الندر تئي مود نـ ايلت تيدت ترفري

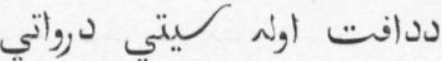

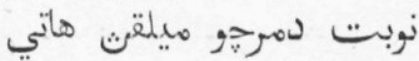

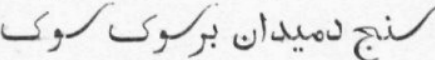
كرله ددالم كركت نوك

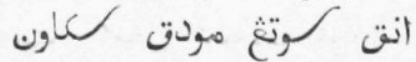

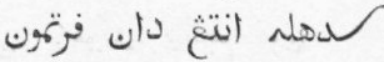
كايب فتت كايب براكي لايي دهيت ديت لايث يثجاد براد

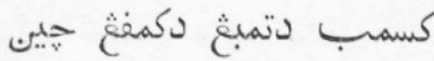

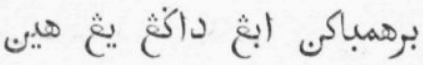

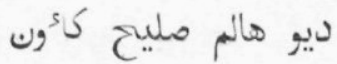

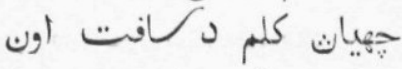

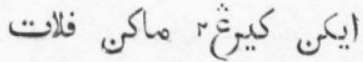
انتت بربندع دثى فركم فرات

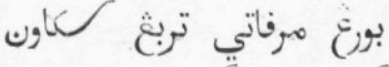

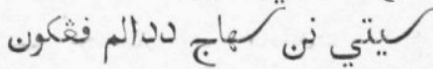
بمبن دبلي ددالم فراهو

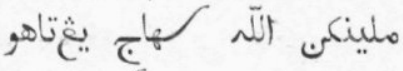

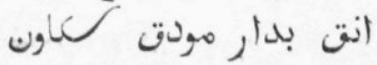

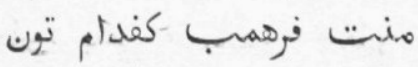

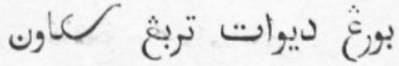

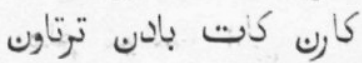

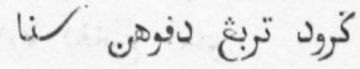
فرهمباك. كنه داكع يثيثين برهمان دودت داتس كماك كاكن

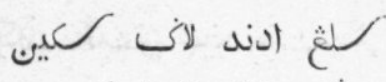
بورغ مرفاتي تربغ كهوم

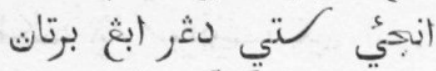

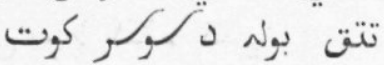

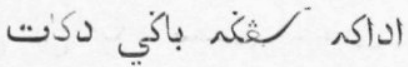

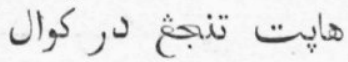
فاتت دجنجع جاد جمال دوال

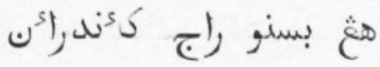
ابغ برتو دثن موتون

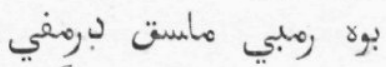

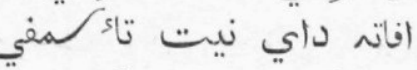

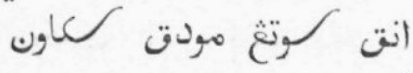

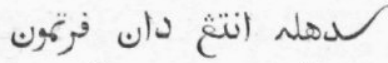

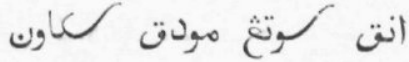

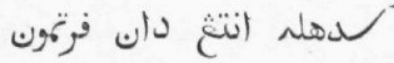

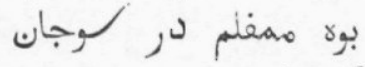

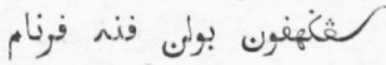

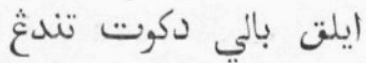

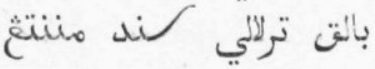
بالي دباثث ديو دأون

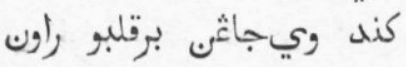
تهبه حنداون دهيلمكن كقغهفون تيدت دظثييركى

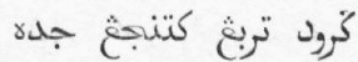

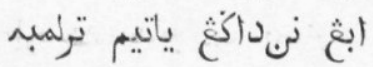

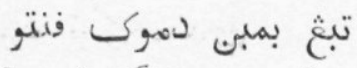

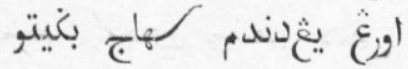

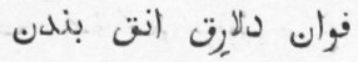

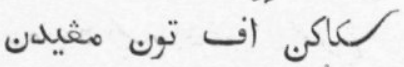
ديو أغكلَ صليح مغمبع 
تيداكه تاكت جيو نه هيلث

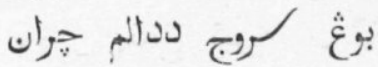
أنيل راج برانت يور يون باثن بهترا دبنو جيمين

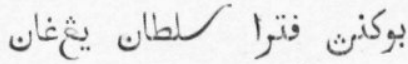

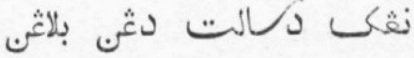
مكاث اكو مربت فن فناثن

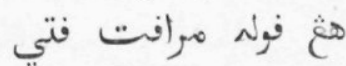
لالمب بولم باكي دهاتي

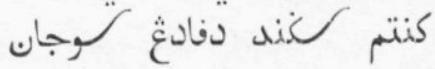

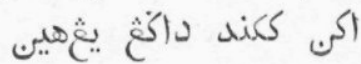
كأناغ دكوبه دجمباثن

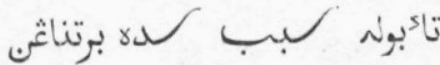

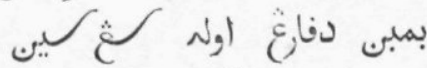

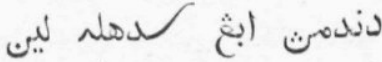

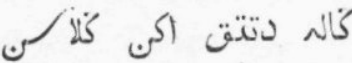
دمي التّلم تيدت ابث كلث لفسكن

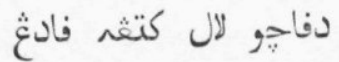

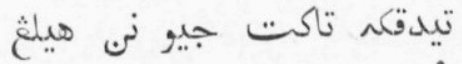

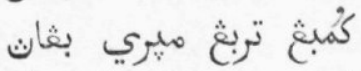

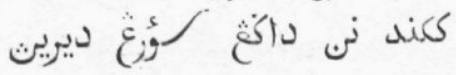
تاليث جاثُ دكندوري

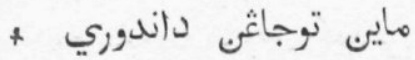
فوديث رات بهن توجات داندوري دبلي ديو نم تيدت كنتر داتئ دابثري انت بليد د لمبر هلث بيت نه اد تهبلث هيلغ هلي ترلتق داتس فيكى فيك لتيا تيدن بيت ديت أوبككي انق دندع ماكث فادي لئي
مثاف برغري يث دمكين

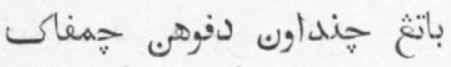

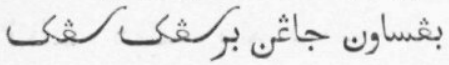
نانَ مغُمبع دلاوته جاتي

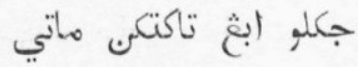
بولم دتتق راكتكن فادي اوري كتيدت تاكتكن ماتي فوكت تراني فاكر بلاث.

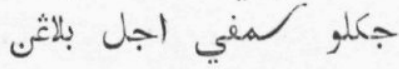
فوهن مشفلس تمبن دفادع

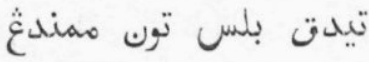

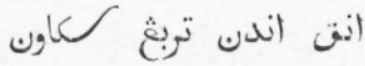

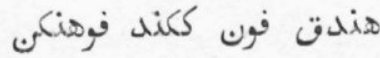

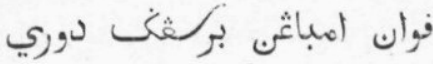
تون جاثم برغ أفك لاكي نقسي كلمان ترب در بنيل مسكيفون تون تيدت رضات درن

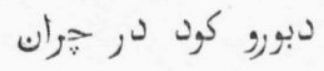
وي كناند يث بجنتسان فوهن مهفلس تجبه دفادع

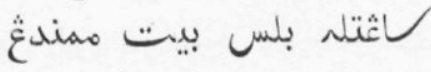

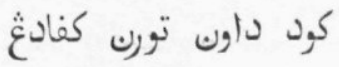
مود بثساون بيرن هيلغ ترون

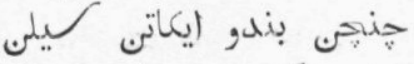
جكس كريبو زغئي مغاون ايكت تمب بك بري برتالي

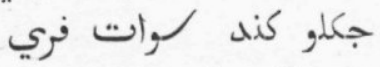

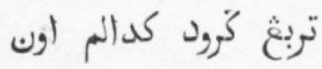

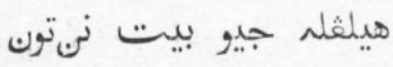

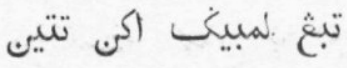


هارفـ تيدق كفه يث لايين

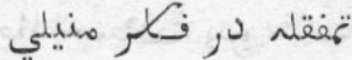
براف هركت بولم دنيلي

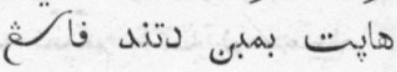

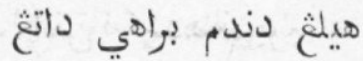

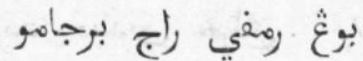

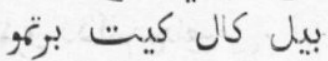

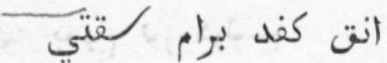

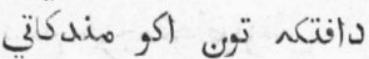
نايكس برتافت دكاكي اون

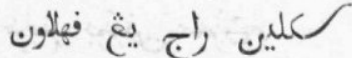
دودق داتس كلئ تيزي تيداله بيت كُنتر دارثري

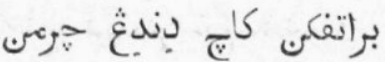

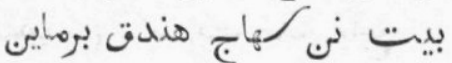
انت هilo بايكله حوب همبوغ هاو تالي ترتهبت دباتث دليم هاتي ترتهبت كلاتم لام

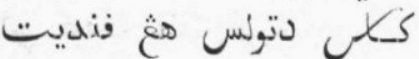

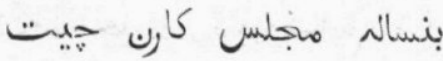

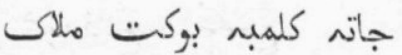

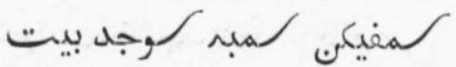
كايث برتكت تني برأب فوهنكن. اوبت هاتي نمرأرن جار بردندن دفيلغ جيمين هاو دان بادن فثيرثكا

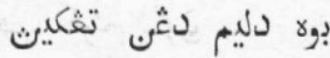

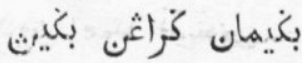
هندت براغكتت لنج دفيلث se volgr. III.
ايو هي ادت جاثر مراوث كونغ بنتى تهفتث مق

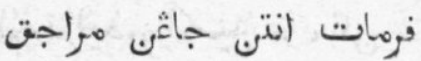

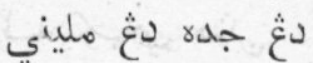

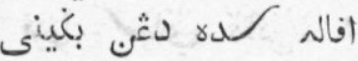

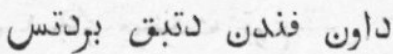

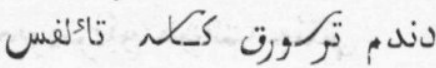
اهبع خليفه راج بثنساوب

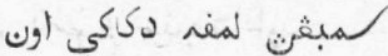
انت كفل برام لمقتي دافتكه تون اكو مندكتي راج جكلو, لقدر راج فيللاجون بالي دباءٔ راج بايو هilي وي جاءٔ تيدق تاهو

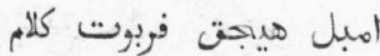
درف هيدف برداتي دندم كود كريمن در جده

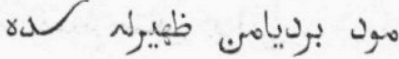
لمبو بوريله در هولهو قلبو ?راهي كلو ترلال لايغ لايث نايكس برتالي

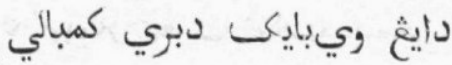
ريكس دكوبر داتس بثكو جك لمبر لمه برلاكو تجب مهفلم دهولو راكث

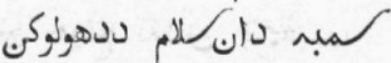

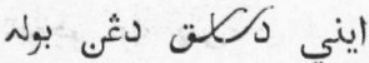
معنل تيدق داتث مهيوره ديو بستاري راج كائدراك 
دودت مراون كُون أورغ

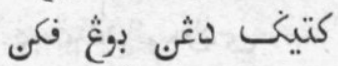

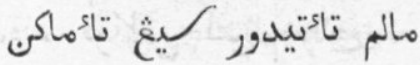
كفلاث جوك مالم تهاي هلاكى

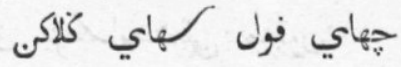

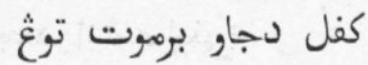

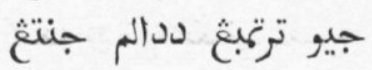

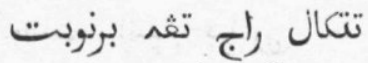

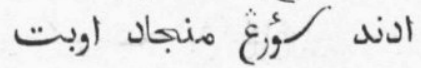

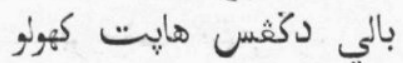
أندر فقسي لايثك. داكي

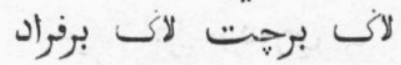

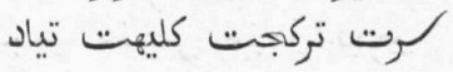
جاتم كدولغ دولغ كاته

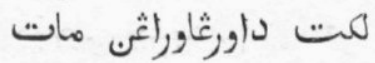

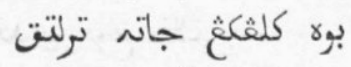

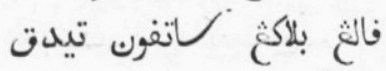

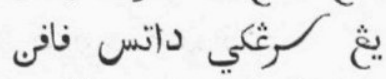

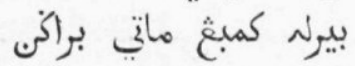

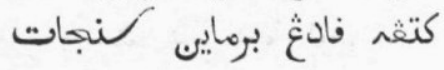

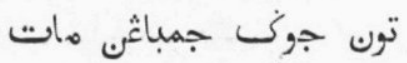
دبوت نول مفيب كايب

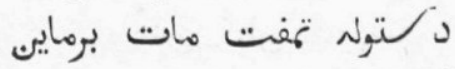
لنتافن انت راج له دجده

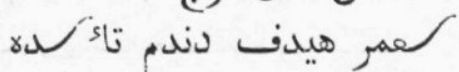

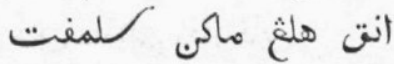

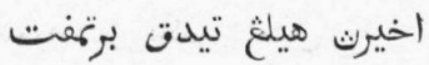

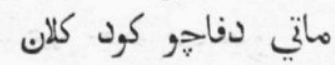

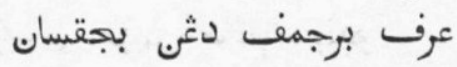
فاتر برانتق كوديي كايب

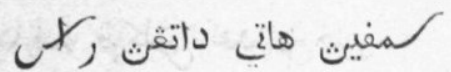

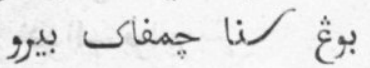
بمبع كلان برجمفر رندا

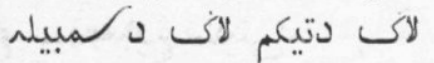

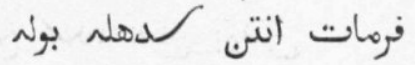
در جرت كنغري جراتي تون تركورة ددالم هاتي هايت كمبث در هولي دمات هاتي بمبع بوريمفر فيلو

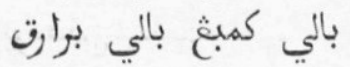
هندت تربغ بوكنث مرت برت بارت

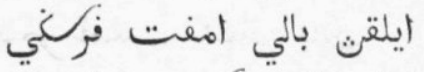

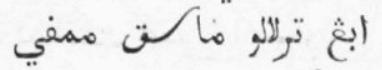
قرطال لر دكنتع لايث لايث

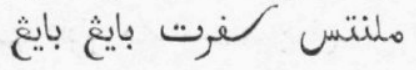
بوه بدار داتس فافن كمنتار دودت برهدافن دوان

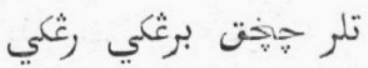
جكلو تيدق كنتم دفاكي

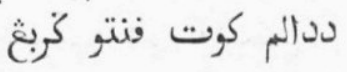

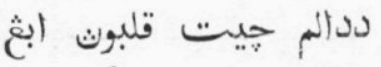

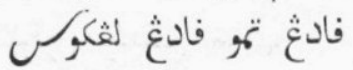

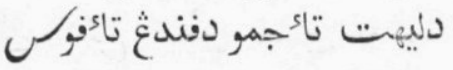

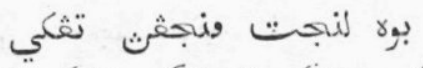

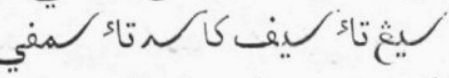
كون تيج ماكى فديكس جكلو بخين رأل مل هاتيكس كون رنتك كود بكن داور

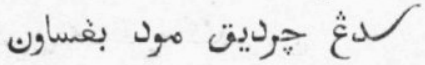

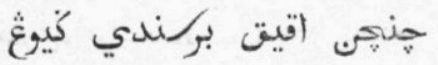




$$
\begin{aligned}
& \text { تيدقله فول }
\end{aligned}
$$

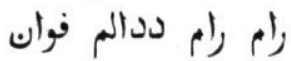

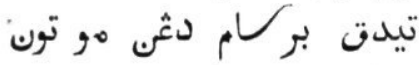

افع جده ادث مليني

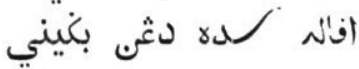

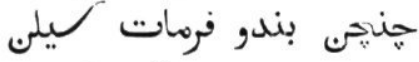

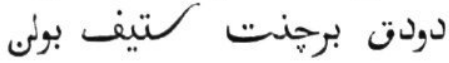

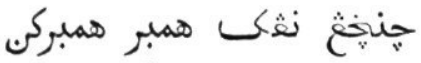

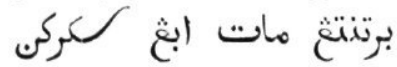
كيلغ بولارو دثر دئ دايده

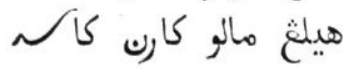
برجاجر امفت دول دالم بلوكر هندق ددافت تمفتث كركر فهى دتمف تابع تاجي جاءٔ دباو بركاكت هاتي

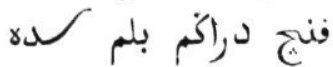
هيلغ ددالم لاوتن كنده فوتس بنغ جالنكى تمبت لاوته تنغ كونغ براهبق هنداون جوكت اكث فثيكتث بثساون جوكت اكث اوبتت

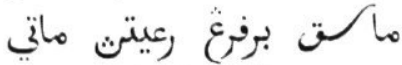
هاتِ دلأع تيدق مثريت هلرن هانوجو بكري بالي كفد هاتي هلده كدهل فاتي لال دامفقكى كبله هاتي داب كتتجقك. بوغ رمفي ددالم فوان بيلاكك. مفعي كفل توني

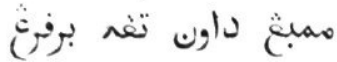

جكلو تيدق دثم تونث لغكور تهب ددالم فادي تيدقله فول لع ددالم هاتي رام رام ددالم فوان

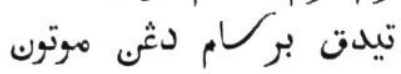
الغ جده ادغ مليني

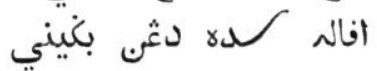

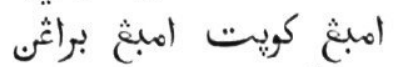
تون كولِت ابثَ لرأَ أيكت برايكت تالي كود هاتي ترايكت كمانث مود ليمو مانس داهت بردوري دودت مناغس مناهن ديري بردنتمله كونت بنه دورين مبند بلمله جنجيه برجدين جكلو فندق بولغ فلاثي جكلو لمبت تون كسباني

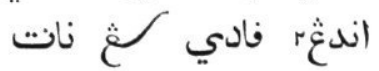

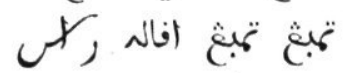
هيلر راكت باتغ هندأون فياكت داتغ در بثساون

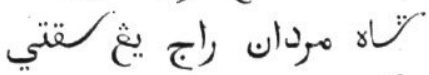

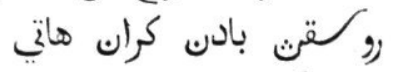

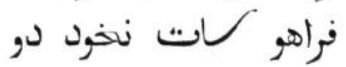
كفد هات تيدالم دور

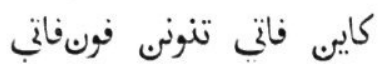
جكلو تيدق تاكتكى مالتي

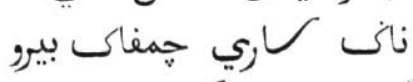

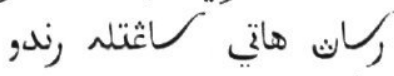

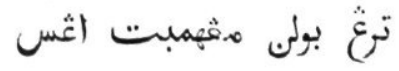


تونك جوك كنئ فرتوب

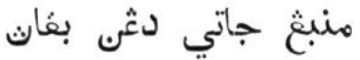

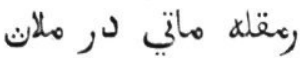

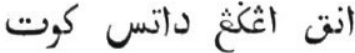

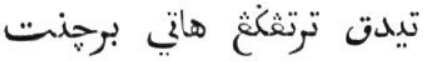

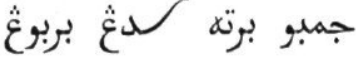

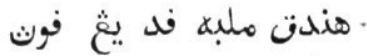

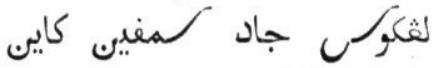

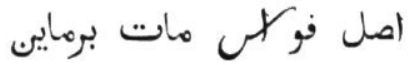
كل داب كاتي داتس كات كت كائ لوكت دهاتي كارب كات دات برانتع بوغ بريبو ريبو

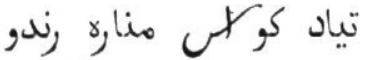

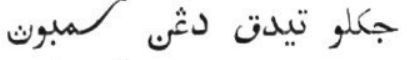

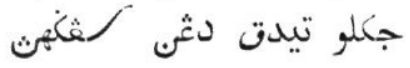

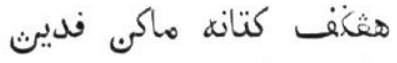

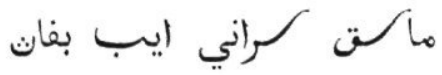
فاتغ رنتع تربثلة دي التي

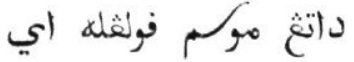
بندن برنامكي راج كايو فئن ككند تيدق همبري مالو انت راج دبنو تأرف

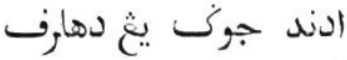

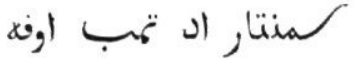
انتار اد كايث فوته كفون دثن رهبو رهبوث

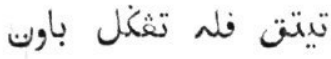

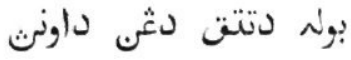

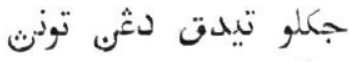

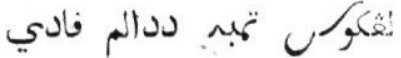

جملو ماتي بير بركلم

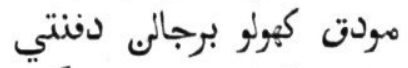

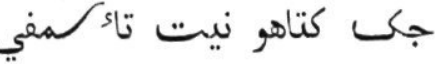
هنبع جاتي دثث بثاث رمقلل ماتي در ملاثل در جمبت كجمبو ايرغ ايت دمبوت هاتيكس بيرغ

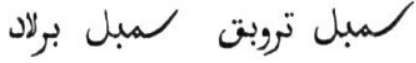
هندت دودت هناك الد كاير كنداكث نوث هيجيو

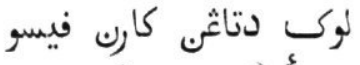
انهي كاجع اورغ ددالم الهبل راهن بير دماكى

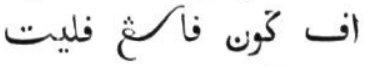
اف كون برهايي مات في فلت بوغ اجي تربغ كهج

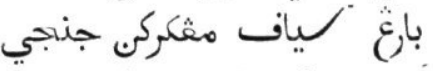
انت اغَّ دكايو تثكي انت داكّث لام د ديث دكي

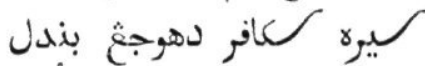
جاثنله تون برهاتي كركّل

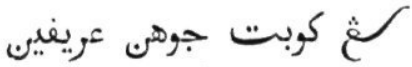

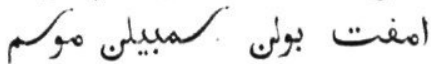

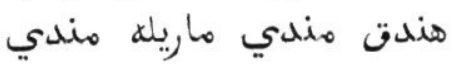
هندت ماتي ماريلك ماتي

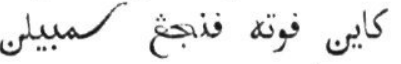

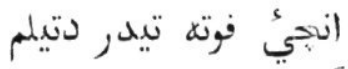

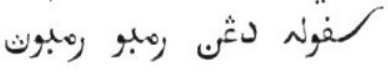

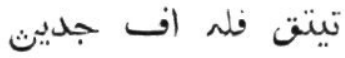
بولم دتتق دث لداونث 
هاث ادند فناور قلبب انق هودث ملات باتث

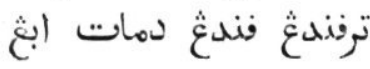
مرفاتي تربع براتس راتس

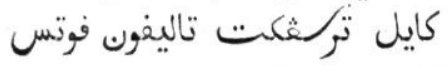

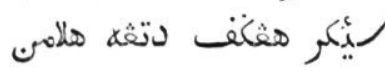
جورث ترلفس درفد تاث.

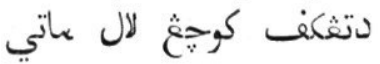
افاله داي دثر بودي لندودق فمغكغ هودث هندق دودت لراغث اورغ 'مبيكت تمبه دباتو باتو لروتر اعبللة ميكـ بوتكر باجيو بولم كا لفس در تهبله

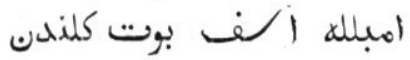

كونت كرغ در زولة فاتهله هارع بوتكم جارع كمبثكن فايغ ككنيغث. رغڤثكى فنتو فراثين.

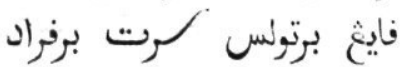
هداثر "لدي هنتئي ككند فايغ تو زهان دهولو كان

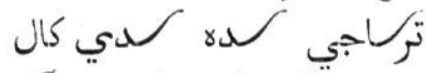

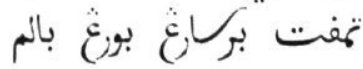
هاتي ترّة هنجاد كلم

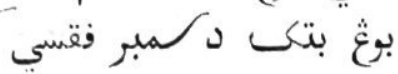
امبللغ ككند بوت بلت فرقسي د لمبر فقسي بركاون كارب جديكن فرقسي دفرادون بوفغ دثم مهبع داون
يغ تراتام هياله تون

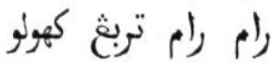
هاث ادند فناور قلب كتيكس فانسله تثغ هاري جك بني ركات هاتي مرفاتي تربغ براتس راتس رات

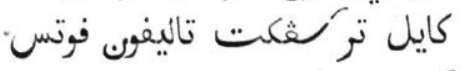
لئكر هغكتف دتثَ هلامب جورن ترلفس درفد تاثم

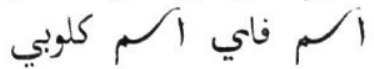
افائل داي دثنث بودي جكس تون فركي كبمبي جنلو تون كألهنب كامي لمبيكـ تهبه دباتو باتو كنتغكى ميكس بوتكى باجو

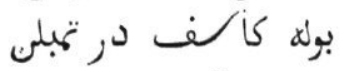
امبلله الولف بولت كلندب كتيكس فازسله تثل هاري كتيكس اغنس داتث كماري كمبثكن فيث ككنيثن

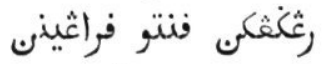

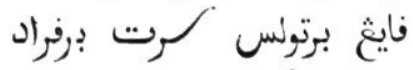
هدأث كدي مننتي كند بوكت كرود كايو هندان مني لحتث مود كنا بنهان فيخه كثكو دتفف دون دوري تون لتسان انته بيدوري

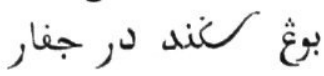
ايو هي ادند هكوت اندرا ديوا لقتي بولئ فرنام 
IETS OVER DE PANTONS DER MALEIJERS.

جكلو اد كرني الله اغخس برنام بورغ كرئ لهين بلس كرت دثر كسيه. هندق ماكى كلوفت جنتع ليافـ لاكس تمفت بركت بكنت تياد فوان كلافس فادي تياد تون كياف وان كلـ لافت داون ترفت داتس بوكت نون

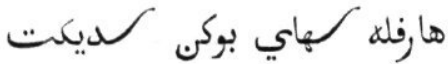

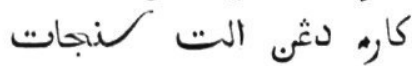
هارفت تياد دافت دكات دان كار دلارت اندر كيري ماتيله كهاي فوهمباك ديري داون بودي بوه بومبث

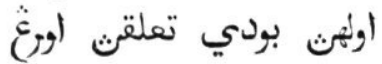
ميسيق رقسي ددالم فوان

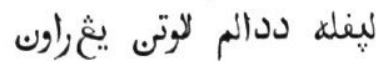
دورغ فلمبع در جار

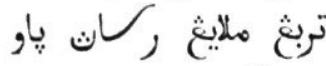
ننه كده برايسي كاين نيتكس تيدت كفد يغلائي

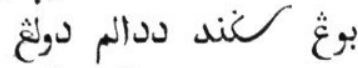
هاثن كفد تون فوان فرنتنـ راج دجار تونله جاد بادن داب يار راج جار مايي. دفادغ جهاي دُرج كنيلغ كميلغ

$$
\text { بوع دئ تراتم دالم هاثم توان }
$$

هوهت موكل

ماكث كِلمَسه براولم اولم

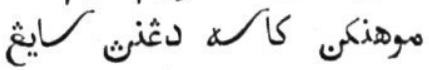
اغخس برنام بورغ لهيه جكلو تيدت بلس دابكسيه بردي - ارت ارت كلافس فوان هارفله لهاي كفد تون تياد فواب كلافس فادي

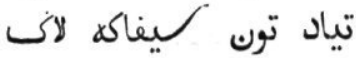
كارب جثكغ منيارفت رنده كونغ تقنيله هارفت منيل

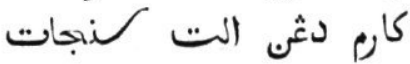
هارفت منفر توتر دابكات كارم دلاوت أندر كيري ماتيله كهاي فهمباكى ديري بوغ كلاسه كنتم كأند كارب كا لم ترحكم ككند هيیت رقسي ددالم فوان ليفله ددالم لاوته يث راون دولغ فلمبع در جاو تربث ملايغ رلاث كود هيتم فلاد كاين نيتكس تيدق كفد يثلايث بوغ لحند ددالم دورغ هان كنف تون كؤغ فوان فركنتف راج دجار تونله جاد بادن دانيار بايق كود ماكى دفادث

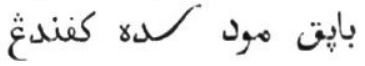
وع دئم ددالم فوان 
جكلو دودت يث دمكيُ. در كر/يت كسورباي دودي

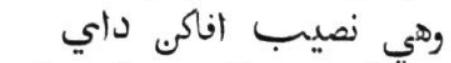

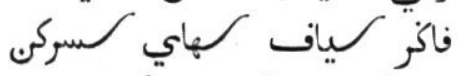

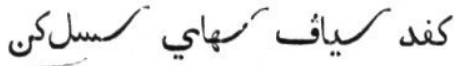

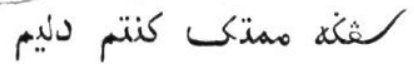

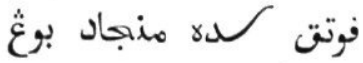

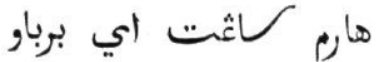

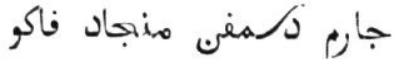

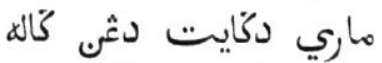

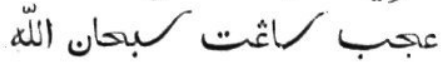
كاله فاته بوغ بنهالك

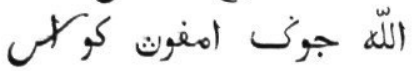
فيسو راوت دوالم فوان

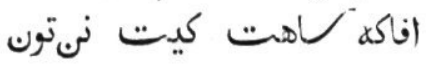
اكث همبله بوه دوكر

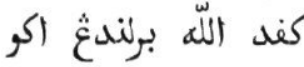
دوكو دبله جاد كفايغ بايكس بركورو كيت كوكلمبهيغ روك بايت ددالم رهبيا دور بايت ددالم دنيا

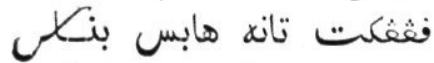

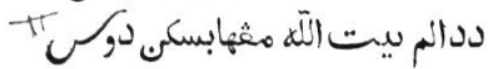
ماري دتودغ بوه ملاك منست لندأ درافي ناركس

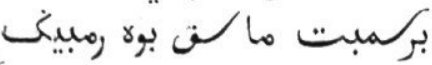

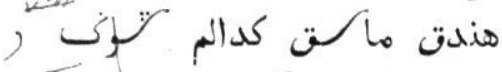

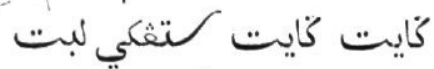

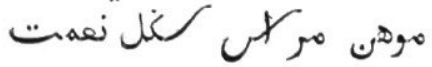
ماري دكايت دثر دمث كانه
روكقله بادن برفنجاثُ بوغ لندودت بوت كريمت بورن جملو دودت يث دمكيّ دركريت كسورباي وهي نصيب افاكث داي تودث لحجي تراندق بنتت

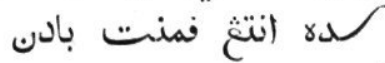
لغغكة ممتكس كنتم دنيم

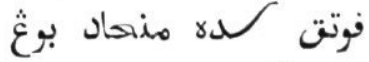

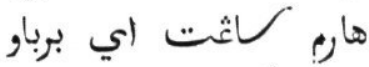
جارم دمنه هنجاد فاك ماري دكايت دثم كُاله

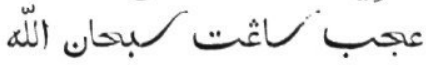
ماكك. دجڤغكر برالس حهران منكر ونكير داتغ برتاث فيسو راوت ددالم فوان افاكه كلهت كيت نمتست اكر همبله بوه دوكو

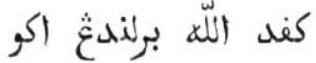
بايكس بربورو كيت كسبرغ

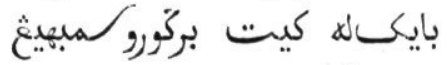

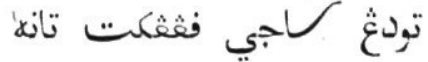
نايكس حج كمكلة مدينه فثغكت تانغ هابس بنـل

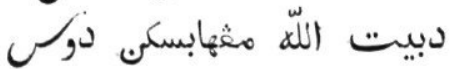
فوهن دكب. هابس بربوه

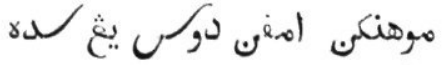

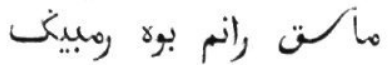

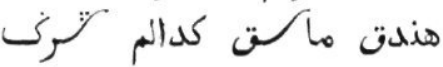

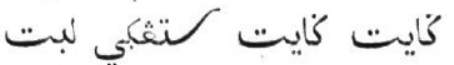


IETS OVER DE PANTONS DER MAIEIJERS.

تيدت ترثفأُ عبارة هعني

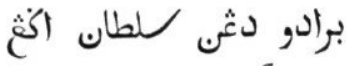

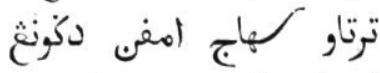

كدواث ايت هنبات النداد راتو

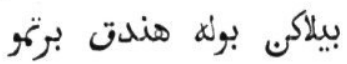

ترلال بايق مناره رعيت ديت

ايكي دلاوت إمفن ددارت

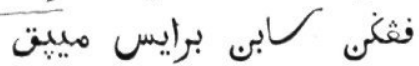

منت امفن باين بايق برايق

ميسيق برنام كراكم بار

منت معاف كات كركات ترلال

توكث داتثلله در كوت كت ترات

دارت برجمفرلة ايرهات

انت جنتايو هندي برندم ارئدم

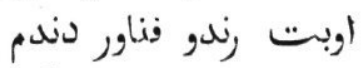

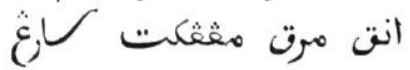

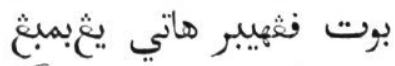

ددالم كبب اد بدار

ددالم فنتت اد بيهار

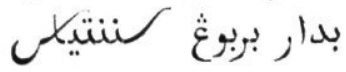

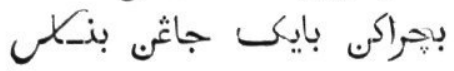

بدار تيدت بربوغ لاكت بائ

افاكه كون بيدار لانس ترن

تربغ كديس كوك بك مننتي

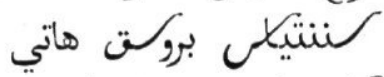

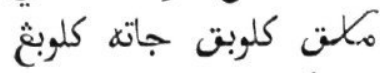

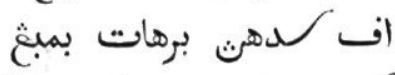

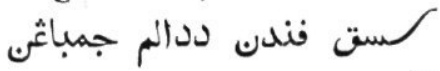

بور بلك بادن برفنجاثن

بوغ لندودن ددالم تامس

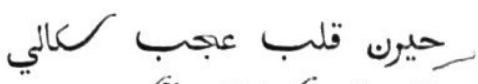
بتار انم كلطان كريق

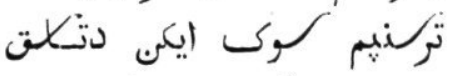

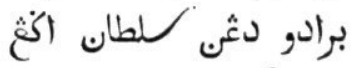

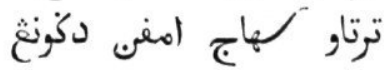

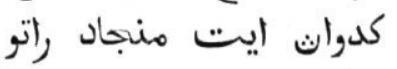
بيلكا بوله هندت برتم

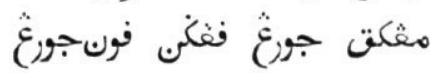

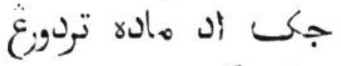

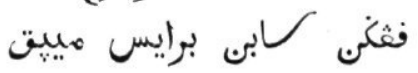
هنت امفن بايق بإيق اين كورت بعارو دتولس بانس

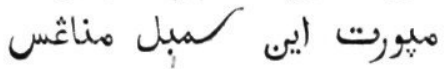
توكثث داتغ در كوت الت داوت برجمفرلة ايرهات انت جنتايو هندي برندم اريتم اربت رندر فناور دندم بندي اورغ بركبن لهاي بركبن

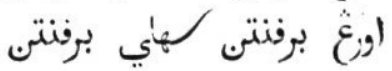
ددالم كبب اد بدار ددالم فنتت اد بيهار

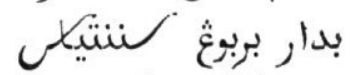

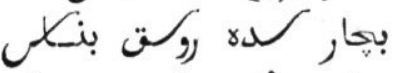

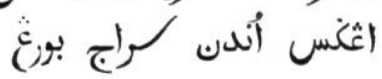
وهي باد أفاله انتع تربة كديس كوك هن منتني

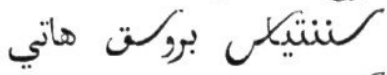
مكت كلوبق جاته كلوبث

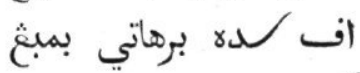
كسق فندن ددالم جمباثن 
فنتت هلايو

توكثث تيدت تاهوكى ارتب

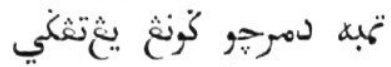
بهيسات اورغ حار ملايو

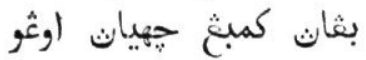
توك نهتيدت ارتيكن هعني كمبع نتيدت برتيدن برنتي كسان

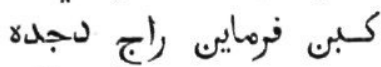

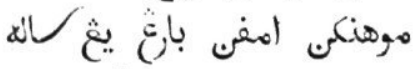
انت عرب هناندي ملمغكو

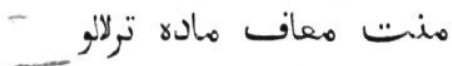
فوجت دكثنس بريبر ريبون

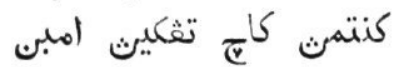
كمبع دارج بالت براله

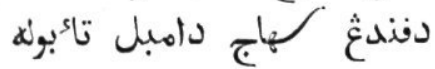

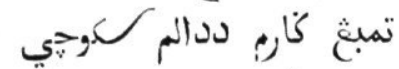
برتمبه كرم ددالم هاتي

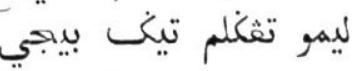

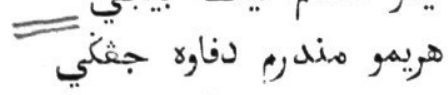
بوه فال ددالم كلتق افي بويال ددالم لوبت دورلم

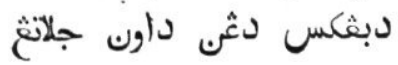

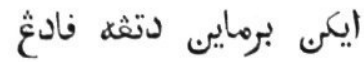
فثيرن راتو جاد دبالي

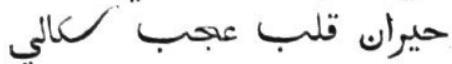

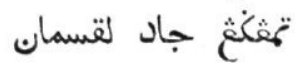

انيلة كورت بهارو دكارغ

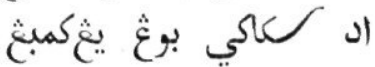
توكثث تيدت تاهوكى ارتي تمبه دمرجو كُنغ يثتنغي بهساث اورغ حار هلايو

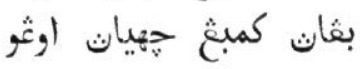
بوع دكارع ددالم كسبن كيا تيدت تاهو برونتتن

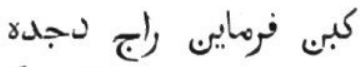

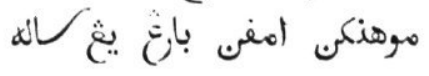

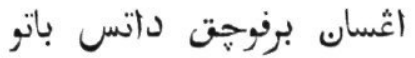
اد بوغ دناوث باتو

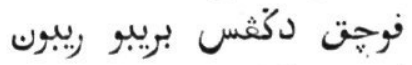

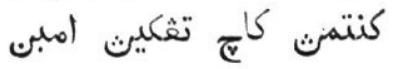
كمبع داوج بالق درأه

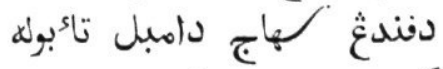
كوثي راي بوكت برغي برافت دامبل تئه بواي برجمور داتس بوكت بوكت بركت

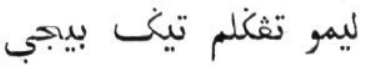
هريمو مندرم دفارو جثلكي تيكي بوه فال ددالم كلت

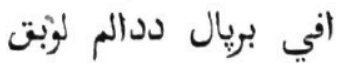

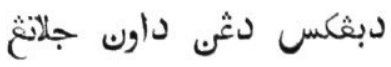

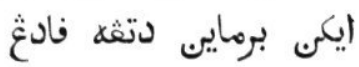
فثيرث راتو جاد دبائي 